Hydroécol. Appl. (2000) Tome 12 Vol. 1-2, pp. 87-134

\title{
An assessment of the effect of the Sizewell power stations on fish populations
}

\section{Effet des centrales de Sizewell sur les peuplements de poissons}

\section{Dr Andrew W.H Turnpenny ${ }^{(1)}$, Colin J.L Taylor ${ }^{(2)}$}

(1) Fawley Aquatic Research Laboratories Ltd, Marine and Freshwater Biology Unit, Fawley, Southampton, Hampshire, SO45 1TW, UK.

(2) Health, Safety \& Environment Division, British Energy, Barnett Way, Barnwood, Gloucester GL4 3RS,UK.

\begin{abstract}
Sizewell A and B Nuclear Power Stations are located on the Suffolk coast of East Anglia. The A station is a 650 MWe Magnox plant, completed in 1966 and operated by British Nuclear Fuels; the B station is a 1258 MWe pressurised water reactor (PWR), commissioned in 1995 and operated by British Energy Generation Ltd.

Both power stations are direct cooled and rely on abstractions of cooling water (CW) from the North Sea: together they can abstract some $80 \mathrm{~m}^{3} \mathrm{~s}^{-1}$. The water is passed around the plant condenser circuits and returned to the sea, along with reject heat and any chlorine residues from antifouling treatment. The abstraction of this water is accompanied, to some extent unavoidably, by entrained fish present either as ichthyoplankton (eggs, larvae and postlarvae of fish), or as fully-formed juvenile or adult fish which have to be removed by mechanical screening systems ('drum' screens) to avoid CW condenser blockage. The entrained ichthyoplankton passes through the entire cooling system and is discharged back to sea along with the heated water. The later life stages of fish and other material that become impinged upon the drum screens are removed from the water. At Sizewell B provision is made to return the more robust species of fish back to the sea alive.

In the late 1970s, the Central Electricity Generating Board (CEGB), then owner of the whole Sizewell site, announced plans to build the PWR power station which was to become known as Sizewell B. Local fishermen lodged an objection to the scheme on the grounds that the mortality of juvenile fish on the drum screens might be increased to an unacceptable level. Between 1981 and 1982 a joint study of the fish catch was carried out by the CEGB and the Ministry of Agriculture, Fisheries and Food (MAFF). This study showed that the losses on the A station of commercially important species, including plaice (Pleuronectes platessa), sole (Solea solea), dab (Limanda limanda), cod (Gadus morhua), whiting (Merlangius merlangus) and herring (Clupea harengus), amounted to 66 tonnes per year ( $\left.t y^{\prime}\right)$, then valued at $£ 28,000$ per annum. This estimate included an allowance for the potential yield of fish which were below the statutory minimum landing
\end{abstract}


sizes when captured, assuming that the rates of growth, mortality and exploitation would have been similar to those experienced by other fish within the North Sea fisheries. The catch rate was summarised by observing that it was 'less than that of a single small, inefficient trawler' and therefore of minor significance. It was also concluded that no impact on local fisheries could be defined, as stocks within the North Sea tend to migrate over large distances. Nonetheless, it was agreed between CEGB and MAFF that a number of reasonably practicable opportunities existed for reducing the catch of the $B$ station, such as appropriate location and design of the cooling water intake and the incorporation of the 'trash' return system. It was also agreed that, following commissioning, the predictions on fish catch would be validated and the relative success of the various mitigative measures assessed. This report is the result of that agreement, but also provides the opportunity of summarising and incorporating other Sizewell-related impingement and entrainment studies to give an updated assessment.

With the construction of the B station, and plans (now dropped) to build a $C$ station, the CEGB's successor and British Energy Generation Ltd.'s predecessor, Nuclear Electric Ltd., commissioned studies both to satisfy the prior agreement with MAFF and further evaluate the actual or potential impact of the Sizewell power stations on North Sea fisheries. So, from 1991 onwards:

* the original survey data were re-analysed to assess any likely changes resulting from trends in North Sea stocks;

* assessments were made of losses due to ichthyoplankton entrainment at the A station;

* experimental studies were undertaken to determine mortality rates of ichthyoplankton passing through the CW system;

* on the commissioning of the B station, catch rates were compared with the A station to determine whether design and positioning improvements in the $B$ station intake were beneficial;

" survival rates on passage through the fish return system on the B station were measured;

" comparisons of losses of juvenile fish due to the power stations with those due to other sources, such as the East Coast shrimp fisheries, were undertaken, to provide an alternative context within which to view the findings;

* an expert system known as PISCES was used to make estimates of impingement rates for other English East Coast power stations, so that the combined effects of these stations acting in concert could be determined;

" other fish-related studies were undertaken to determine, for example, any possible impact of fish losses on the availability of food for fish-eating birds at the neighbouring Minsmere nature reserve.

The results of these studies are frequently presented in this report in terms of Equivalent Adult values (EAV's). The EAV method is a procedure where the numbers of fish of any age are standardised to the number that would be expected to be alive at the age when $50 \%$ of the stock would mature. Thus, if a fish matures at 3 years old, many millions of eggs or larvae may represent a single 'equivalent adult', and the EAV will be a tiny fraction of unity, whereas a fish older than 3 years will have an EAV of greater than one. The purpose of the EAV method is to allow fish captured at any stage of their life cycle to be compared on an equal footing with fish of commercial size. It is important to note that the EAV method does not take account of density-dependent factors (such as rates of predation, parasitism, feeding success) that might tend to increase the survival, growth and reproductive rates of individuals left in the population when some of their competitors are removed. The values given should therefore be regarded as overestimates. 


\section{Conclusions}

* Comparison of the predicted losses of commercial fish species due to impingement and entrainment at Sizewell A and B Power Stations with commercial landings from adjacent waters (ICES area IVC) shows that the power stations losses amount to about half of one percent $(0.54 \%)$ of the recorded UK and international landings (year: 1994) when expressed in Equivalent Adult terms. Of the individual species, Equivalent Adult losses of only sole $(1.5 \%)$ and herring $(5.8 \%)$ exceeded one per cent of the commercial landings figures.

* The commercial value of the losses due to both stations is estimated at $£ 0.52$ million per annum (*), with the bulk of this value being ascribed to losses of sole ( $\{304,425: 93 \%$ as entrained eggs, remainder impinged), whiting ( $\{83,821 ; 100 \%$ as impinged juveniles or adults) and herring ( $\{116,227: 24 \%$ as entrained larvae/post-larvae, remainder impinged).

* The commercial value of the loss due to the B station $(£ 305,853)$ is estimated to be only $40 \%$ higher than that due to the A station, despite the fact that the $\mathrm{CW}$ demand is twice as large. This reflects improvements in intake design and location, and the successful operation of a fish return system on the B station.

Keywords. - Entrainment, impingement, fish return, power plant, Equivalent Adult Values, bycatch, North sea

Résumé. - Les deux tranches de la centrale nucléaire de Sizewell ("*) sont refroidies par un circuit ouvert, consommant $80 \mathrm{~m}^{3} / \mathrm{s}$ d'eau, prélevée dans la Mer du Nord. Après filtration et traversée des condenseurs, l'eau échauffée est rejetée en mer avec des résiduels de chloration résultant du traitement de protection des circuits de refroidissement contre les salissures biologiques.

Ce prélèvement dans le milieu naturel occasionne, inévitablement, un certain entrainement d'œufs, larves et post-larves de poissons, de juvéniles ou de poissons adultes. Une partie de l'ichtyoplancton parvient à traverser l'ensemble du circuit de refroidissement de la centrale jusqu'à son retour en mer, via le rejet des effluents thermiques. Par contre, l'autre partie du plancton et les stades plus âgés (juvéniles et adultes), ainsi que les autres corps flottants, sont retenus par les tambours filtrants installés en stations de pompage pour éviter l'obstruction des condenseurs.

Pour répondre aux objections des professionnels de la pêche craignant une mortalité inacceptable de juvéniles à l'occasion du projet de construction de Sizewell $B$, décidée à la fin des années 1970, des mesures ont été prises par le CEGB (Central Electricity Generating Board), l'ancien propriétaire, pour restituer au milieu environnant les espèces les plus robustes.

Pour ce faire, en 1981 \& 1982, une étude conjointe des captures de poissons fut entreprise par le CEGB et le Ministère de l'agriculture, des pêches et de l'alimentation (MAFF). Cette étude montra que les prises d'especes commerciales, notamment de plies (Pleuronectes platessa), de soles (Solea solea), de limandes (Limanda limanda), de morues (Gadus morhua), de merlan (Merlangius merlangus) et d'harengs (Harengus clupea), atteignaient, à la tranche A, 66 t /an, correspondant à environ 280000 FF/an.

(") all at 1994 market values, Lowestoft Fish market.

(**) située sur la côte Est de l'Angleterre (Suffolk, East Anglia); elle comporte un réacteur Magnox de 650 MWe, en service depuis 1966, géré par British Nuclear Fuels Ltd (usine A) el un réacteur à eau pressurisée de 1258 MWe (usine B), fonctionnant depuis 1995 et appartenant à British Energy Generation Ltd. 
Cette évaluation incluait la biomasse potentielle des jeunes individus non commercialisables, estimée sur la base des taux de croissance, de mortalité et d'exploitation observés sur des peuplements analogues de pêcheries en Mer du Nord. L'effet de la tranche A apparut comme peu significatif, car inférieur à celui d'un petit chalutier, de faible rendement. De même, il fut conclu qu'il n'y avait pas d'impact sur les pêcheries locales en raison des larges aires de migration de ces espèces à l'échelle de la Mer du Nord.

Néanmoins, if fut décidé par le CEGB, en accord avec le MAFF, plusieurs améliorations techniques (localisation et conception de la prise d'eau, système de retour en mer des individus capturés) pour permettre de réduire les prises à la tranche $B$; de même, il fut prévu, qu'en période de fonctionnement, serait réalisée une vérification des prédictions d'impact et de l'intérêt des mesures techniques prises pour le réduire.

Mais, avec la construction de la tranche B, et dans l'optique d'une tranche $C$ (actuellement différée), les études reprirent, à partir de 1991, pour répondre à la demande du MAFF concernant la prévision de l'impact de l'ensemble des tranches sur les pêcheries de la Mer du Nord; elles ont porté notamment sur :

* une actualisation des études initiales pour connaitre les évolutions des peuplements de la Mer du Nord,

* une analyse concernant les pertes d'ichtyoplancton liées à Sizewell A,

" une comparaison des captures entre A et B pour vérifier l'intérêt du dispositif de prise d'eau de $B$, amélioré par rapport à $A$,

* l'étude du taux de survie lié au système de retour en mer des captures aux tambours,

* la comparaison des pertes de poissons juvéniles liées à la centrale par rapport aux autres causes, comme les pêcheries de crevettes sur la côte Est, afin de mieux comprendre le contexte et la signification des résultats obtenus,

* une évaluation des captures d'autres centrales installées sur la même côte, à partir du modèle PISCES, pour estimer leur impact combiné,

* ainsi que d'autres études comme, par exemple, l'effet possible d'une diminution de la ration alimentaire d'oiseaux marins piscivores vivant, non loin, dans la réserve naturelle de Minsmere.

Cet article présente la synthèse de ces divers programmes, ainsi que d'autres études plus spécifiques concernant les phénomènes d'entrainement à la centrale de Sizewell. Les résultats de ces études sont rappelés tout au long de cet article, en termes de "valeurs équivalentes adultes" (EAV), correspondant à l'importance reproductive potentielle des individus capturés. Ainsi, si la maturité d'une espéce est de 3 ans, de nombreux millions d'œufs de cette espèce peuvent, en fait, ne donner lieu qu'à un " survivant équivalent" ; l'EAV sera alors une faible fraction de l'unité. Par contre, pour la capture d'un poisson d'âge supérieur à 3 ans, ce critère sera plus grand que un. Le but de cette méthode est de permettre la comparaison, toutes choses égales par ailleurs, des captures à différents âges du cycle de développement par rapport à la taille commerciale des pêcheries. Il est important de noter que cette méthode ne prend pas en compte les facteurs dépendants de la densité (tels que les taux de prédation, de parasitisme et de nutrition) qui pourraient tendre à augmenter les taux de survie, de croissance et de reproduction des populations résiduelles, quand certains de leurs compétiteurs sont capturés. C'est pourquoi, les valeurs obtenues peuvent être considérées comme surestimées.

En conclusion, il apparaît que:

* les pertes commerciales prévisibles dues au fonctionnement de Sizewell A et B représenteraient environ $0,5 \%$ des prises anglaises et internationales (exprimées en équivalents adultes), débarquées en 1994 dans le carreau adjacent ICES IVC. Au niveau des 
espèces, seules les EAV soles $(1,5 \%)$ et harengs $(5,8 \%)$ excèderaient $1 \%$ des débarquements commerciaux correspondants.

* la valeur commerciale des pertes dues aux deux tranches est estimée à environ 5 MFF/an "), dont -3 MFF pour la sole (provenant pour $93 \%$ des œufs détruits lors du transit), $\sim 1$ MFF pour le hareng (due pour $24 \%$ à la capture de larves et post-larves) et pour 0,8 MFF au merian, exclusivement sous formes de juvéniles et d'adultes.

* La valeur commerciale des captures dues à Sizewell B ( 3 MFF) ne serait que $40 \%$ plus élevée que celle de $A$, pour un débit de refroidissement double. Cette diminution relative de l'impact résulte des améliorations dans la localisation et la conception de la prise d'eau, ainsi que l'efficacité du système de retour au milieu naturel de la tranche B.

Mots clés: Entrainement, piégeage, retour en mer, centrale électrique, Equivalent Adulte (EVA), pêches accessoires, mer du Nord

\section{INTRODUCTION}

\subsection{Background}

Sizewell A and B nuclear power stations are located on the eastern coast of Suffolk, England. The adjacent coastal waters of the North Sea contain important and prosperous fisheries for a number of species. The most important commercial species are plaice (Pleuronectes platessa), sole (Solea solea), dab (Limanda limanda), cod (Gadus morhua), whiting (Merlangius merlangus), herring (Clupea harengus) and bass (Dicentrarchus labrax).

In the 1980's, the proposal to build a pressurised water reactor (PWR), to be known as Sizewell $B$, gave rise to concern by local fishermen that losses of juvenile fish drawn into the cooling water (CW) system could adversely affect the success of commer- cial fishing in the region. The capture of juvenile fish by the fishing industry is restricted through net mesh-size regulations and by the imposition of statutory minimum landing sizes for certain species.

These concerns were addressed by a study undertaken jointly by the Marine Biology Unit of the Central Electricity Generating Board (CEGB) and Ministry of Agriculture, Fisheries \& Food (MAFF). Fish catches were monitored over a 12 month period, from May 1981 to April 1982. The results of this study were published and presented at the Sizewell B Public Inquiry in 1983 (Turnpenny et al. 1983).

In 1992, Nuclear Electric Ltd. (NEL, a successor of CEGB) was considering the construction of two additional PWR units on the site, known as the Sizewell C Twin option. In this context NEL commissioned a re-analysis of the 1991-2 survey data, updating the fisheries statistics. The

(1) en valeurs 1994, à la criée de Lowestoft. 
operation of the $A, B$ and $C$ stations would have increased the water abstraction rate by a factor of up to six over that of the A station alone $\left(25 \mathrm{~m}^{3} / \mathrm{s}\right)$. The potential effects on the fisheries of these increased rates of abstraction were reported in Turnpenny and Henderson (1992). At this point the debate was also opened to consider the effects of all the operational power stations sited on the East Coast of Britain. In the absence of fish capture data for all of the sites in question, use was made of PISCES, an expert system developed for NEL to predict the numbers of fish and crustaceans captured by a coastal power station.

Between 1992 and 1994, with the commissioning of the $\mathrm{B}$ station and the possible $C$ project, several further studies were prompted by NEL that increased the knowledge of the pattern and significance of fish capture. These included:

- a study which put juvenile fish capture rates by the power station into the context of the 0-group fish bycatch of the East Coast shrimp fishery (Turnpenny, 1993);

- a comparison of captures on the $A$ and $B$ station screens (Fleming et al. 1994);

- a study of survival of fish in the B station fish return system (Seaby 1994).

The last two of these studies were the first time that further fish capture data for the power station had been collected since the original 1981-2 study. The database was further ex- tended by a 12-month survey undertaken between 1992 and 1993. This survey was used to estimate the ichthyoplankton (fish eggs, larvae and post-larvae) entrainment rates at the Sizewell power stations (Bamber et al., 1993), previous studies having dealt with only fish large enough to be retained by the drum screens $110 \mathrm{~mm}$ square mesh opening) which filter the CW stream. A laboratory-based simulation apparatus, known as the Entrainment Mimic Unit (EMU), was developed to enable exposure of fish eggs and larvae to the physical and chemical stresses associated with entrainment (e.g. Bamber and Seaby, 1993). It was thus possible to estimate the mortality rates of entrained ichthyoplankton and to incorporate these into an overall assessment of the fish losses at the power stations. Finally, analyses were undertaken to determine whether or not the removal of fish by the power stations could have any negative effects upon the available food supply for fish-eating birds at the adjacent Minsmere nature reserve (Bamber, 1994).

This body of information about the effects on fish of a coastal power station complex is the most comprehensive ever undertaken in the UK. The present document (Sections 2 to 9) provides a review in roughly chronological order of the fisheries work carried out at Sizewell; Section 10 then goes on to provide a combined assessment of the $A$ and $B$ stations on fish, using all of the available information. This offers a more comprehensive assessment of the impacts on 
fisheries of these two power stations than has previously been available.

\subsection{The Sizewell Site}

To understand the environmental issues addressed by this study it is important to know a little about the habitat within which the power stations operate and the effects that the power stations could have on the marine environment.

The Sizewell power stations are sited behind the Sizewell shore, near Leiston in Suffolk. Thermal power stations such as those at Sizewell tend to be situated close to the sea so that they can draw seawater to use for cooling the steam condenser circuits. A typical nuclear power station requires $30-40 \mathrm{~m}^{3} \mathrm{~s}^{-1}$ (cumecs) of cooling water (CW) for every 1000 megawatts-electric (MWe) generated. The water is pumped into the stations via large ( $3 \mathrm{~m}$ diameter) tunnels from offshore intake points that open close to the sea bed. These abstraction points are situated in a sufficient depth of water to ensure that they are never exposed at the lowest spring tide. The A and B station intakes at Sizewell are located about $300 \mathrm{~m}$ and $600 \mathrm{~m}$ offshore, respectively. The older A station intake is a simple vertical shaft protected by a horizontal grill, which therefore draws water vertically down. The B station has a pair of intakes of a more advanced, capped design, which create lower entrance velocities and a hori- zontal inflow pattern more suited to fish avoidance.

Before the seawater can be passed through the condensers it must be screened to remove large objects which could block condenser tubes. For this purpose large-diameter revolving drum screens are fitted with $10 \mathrm{~mm}$ square-opening mesh. Any fish that are drawn in with the cooling water are trapped and removed by these screens, which rotate continuously and are back-washed into collection hoppers. After passing through the station the now warmed and often chlorinated water is returned to the sea. Small animals and plants including planktonic fish eggs and larvae pass through the $10 \mathrm{~mm}$ screen meshes and are returned to sea with this warmed water. The water temperature in the discharge is typically $8-10^{\circ} \mathrm{C}$ above ambient; chlorine, when present, is injected to achieve a residual concentration of $\sim 0.2 \mathrm{ppm}$ at the condenser, which decays to around half of this at the point of discharge (Coughlan and Davis, 1985).

The fish stocks around the British coasts are divided into discrete areas for stock monitoring and management purposes, under a scheme operated by the International Council for the Exploration of the Sea (ICES). The Sizewell power stations border the waters of a region known as ICES area IVc. This is one of the most important fishing areas within British waters and has been heavily fished for generations. It is now considered to be over-fished and in recent years 
stock conservation measures have been introduced for some species, based on minimum landable fish size, allowable mesh sizes in net fisheries and catch quotas.

The coastline directly in front of the power station has a moderately exposed sand and shingle beach and a seabed consisting of gravel, sand and mud. The inshore zone along this coast is used as a nursery area by a number of commercial fish species, notably flatfish.

\section{FISH IMPINGEMENT AT THE A STATION (1981-2)}

\subsection{Background}

In the early 1980 s, the proposal to build Sizewell B Power Station gave rise to concern by local fishermen. It was suggested that losses of fish, due to increased numbers that would be impinged on the cooling water intake screens of a larger power station complex, would adversely affect the success of commercial fishing in the region. These concerns were addressed through a joint CEGB and MAFF study of the catch of the existing A station at Sizewell (Turnpenny et al., 1983). Fish catches at the $A$ station were monitored over a 12 month period from May 1981 to April 1982. The catch rates of all species were estimated and adjusted to average power station operating conditions and average annual fish abundance figures.

\subsection{Methods for the 1981-2 Survey}

\subsubsection{Sampling}

The fish captured on the screens of Sizewell Power Station (cooling water requirement: $30.4 \mathrm{~m}^{3} / \mathrm{s}$ ) were sampled using plastic mesh baskets placed so as to intercept the backwash flow from the $\mathrm{CW}$ screens. The fish were identified to species, measured and counted. This procedure was repeated on selected days over a 1 year period starting in May 1981. The sampling programme was designed using statistical theory to produce a valid estimate of the total annual catch, using a stratified-random procedure (Murarka and Bodeau, 1977). The year was divided into quarters and at least ten one-day samples were taken within each quarter. The dates upon which the samples were taken were chosen using a table of random numbers. The quarters ran from May-July 1981, AugustOctober 1981, November 1981 - January 1982 and February - April 1992.

\subsubsection{Data Analysis}

The objective of the analysis was to assess the importance, to the commercial fishery, of the loss of fish due to impingement on the power station $\mathrm{CW}$ intake screens. The analysis focused on six species: plaice, sole, dab, whiting, cod and herring. These species were chosen in consultation with MAFF as the only species of commercial importance within the region. Bass, at that time, was not considered important locally. Apart from 
recording details of the numbers captured and their sizes, other species were not analysed.

Catch data were analysed in the same way for each of the above commercial species. The detailed procedure is shown in Figures 1 and 2. For simplicity, all fish captured within each quarter were assumed for the analysis to have been caught at the mid-point of their respective quarters. Two estimates were generated. First the estimated average annual catch of commercial-sized fish. Second, an assessment of the future loss to the fishery caused by impingement of juvenile fish that were too small to have any immediate commercial value. The latter assessment provided an estimate of the impact of capturing undersized fish, about which the commercial fishermen were most concerned. In fact, it represented a 'worst case', as it assumed no density-de- pendent changes in mortality and growth rates which, in practice, could have been expected to offset the losses to some degree.

\subsection{Main Results of the 1981-2 Sizewell A Analysis}

A summary of the catch data used in this analysis is shown in Table 1 , which shows the mean daily catches of the main species, estimated for each quarter of the year.

The analytical results were presented as estimates of the annual catch rate by the A station, standardised as shown in Figure 1 to average stock year-class-strength and average station $\mathrm{CW}$ demand calculated for the preceding 5-year period. This is known as the Annual Total Standardised Catch (ATSC). Table 2 shows the ATSC for both commercial-sized

Table 1. - The mean daily rates of capture of individuals of the main commercial species for each month of the year recorded during the Sizewell A power stalion, 1981-2.

(Units are individuals per day; standard deviations are given in parentheses).

Tableau 1. - Captures moyennes journalières des principales espèces par la centrale de Sizewell A pour chaque mois des années étudiées (1981-2)

(Les unités sont données en individus /jour et les écarts types entre parenthèses)

\begin{tabular}{|c|c|c|c|c|c|c|}
\hline Species & June & September & & January & March & Peak Month \\
\hline Bass & $2.2(1.3)$ & $0.5(1.0)$ & & $36(49)$ & $2.3(1.7)$ & January \\
\hline Cod & $4.4(3.8)$ & $0.5(1)$ & & $31(2.8)$ & $36(18)$ & March \\
\hline Whiting & 327 (373) & $155(160)$ & & $863(641)$ & $1007(260)$ & March \\
\hline Herring & $48(34)$ & $555(555)$ & & $1044(637)$ & $406(75)$ & January \\
\hline Sole & $5.2(5)$ & $60(60)$ & & 0 & $104(40)$ & April \\
\hline Dab & $12(21)$ & $103(151)$ & & $68(35)$ & $3(0.8)$ & September \\
\hline Plaice & $1.4(2.1)$ & $57(48)$ & & $18(0)$ & $61(35)$ & September \\
\hline Totals & 400 & 931 & & 2060 & 1619 & \\
\hline
\end{tabular}




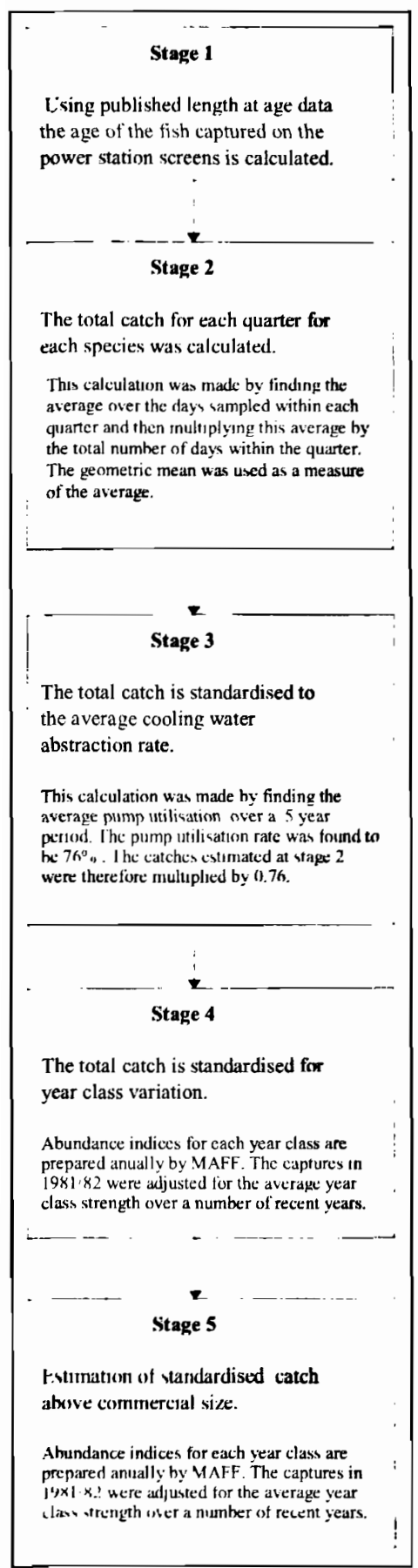

Fig. 1. - Estimating the annual loss of commercial fish (1981-2 study)

Fig. 1. - Estimation des captures annuelles d'espèces commerciales en 1981-2

The first stage in the analysis was to determine the age of each of the fish captured. This was achieved using published data giving the range of observed lengths for fish of a given age. Fish were assigned to the most probable year-class of origin, defined by their year of birth. The great majority of the captured fish belonged to the 1980 , 1979, 1978 and 1977 year-classes.

The second stage was to estimate the total catch by Sizewell A Power station for each species for each quarter. The geometric mean " daily catch was calculated for the period. This was then multiplied by the number of days in the period to give the total estimated catch. The geometric mean was used because the catch data were not normally-distributed and it was considered that the arithmetic mean would overestimate the catch. A problem with the geometric mean is that it cannot be calculated for data sets with zero values, so it was necessary to add 1 to each daily catch. In practice this would introduce little error.

The third stage was to adjust the estimates of the quarterly captures for variation in the power station cooling water abstraction rate. The average abstraction rate for the 5 year period 1977-1981 was calculated. Under the assumption that the number of fish captured was directly proportional to the volume of water pumped, the estimated quarterly catches were adjusted to the average volume. It was found that the average pump utilization rate over the five years was $76 \%$.

The fourth stage was to adjust the estimates for yearclass strength variation. Not every year is favourable for fish reproduction and this results in large between-year variations in the abundance of young fish. This variation could produce inaccurate estimates. For example, if the $1981 / 82$ sampling period coincided with a year of low recruitment then the average number of individuals captured over a number of years would be underestimated. Abundance indices are prepared annually by MAFF for the various stocks. These were used to adjust the estimated catch for the year of sampling to the average abundance calculated for each species over a number of years. Unfortunately, year-class abundance data are not available for dab.

Stage five was to estimate the average number of fish captured per annum which are above the statutory minimum commercial landing size (MCLS). To conserve fish stocks, MAFF sets statutory limits on the minimum size of fish that fishermen are allowed to land. An MCLS is set for each of the main commercial species. For each species, the fraction of the power station catch that was above the minimum landing size was determined. This was multiplied by the standardised catch to calculate the Annual Total Standardised Catch (ATSC) of landable-sized fish.

(1) More strictly, the 'population geometric mean' (Rahman, 1968) was used, as it is considered to yield more unbiased results when dealing with fish capture data. 
Table 2. - Sizewell A power station, 1981-2 study. Annual total standardised catch by number of individuals of commercial species for fractions above and below minimum commercial landing size (MCLS).

Tableau 2. - Captures annuelles de la centrale de Sizewell A en 1981-2, par nombre d'individus des espèces commerciales de taille supérieure ou inférieure à la taille commerciale.

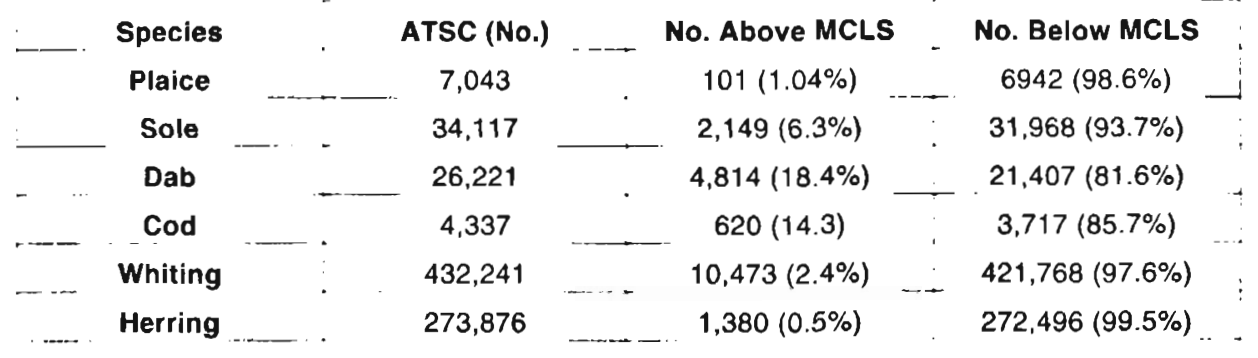

Table 3. - Sizewell A power station, 1981-2 study. Estimated annual loss to the fishery of commercial-sized fish due to CW abstraction.

Tableau 3. - Estimation des pertes annuelles des espèces commercialisables en 1981-2 dues au circuit de refroidissement de la centrale de Sizewell A.

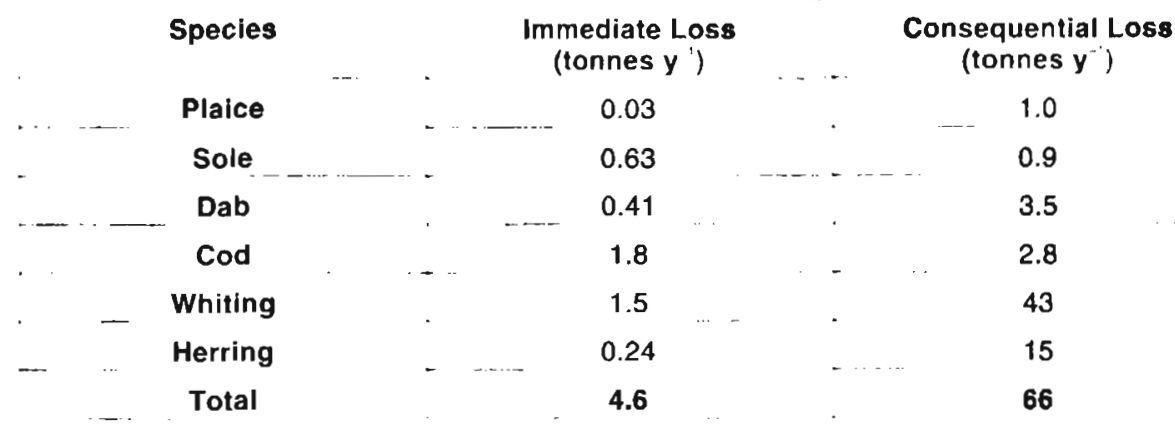

Table 4. - Comparison of annual fish loss due to Sizewell A power station with annual losses due to commercial fishing vessels (\% of North Sea stock).

Tableau 4. - Comparaison des captures annuelles de Sizewell A et de la pêche commerciale (en \% du stock de mer du nord)

\begin{tabular}{|c|c|c|c|c|}
\hline Species & & $\begin{array}{l}\text { Stock Size } \\
\text { (millions) }\end{array}$ & $\begin{array}{c}\text { Power Station } \\
\%\end{array}$ & $\underset{\%}{\operatorname{Commercial}}$ \\
\hline Plaice & & 685 & 0.00072 & 17 \\
\hline Sole & & 210 & 0.013 & 23 \\
\hline Dab & & 4,900 & 0.00034 & $?^{(3)}$ \\
\hline Cod & & 845 & 0.00044 & 53 \\
\hline Whiting & & 3,500 & 0.0087 & 47 \\
\hline Herring & & 7,460 & 0.0017 & 15 \\
\hline
\end{tabular}

(2) Reliable commercial landings records are not available for dab. 


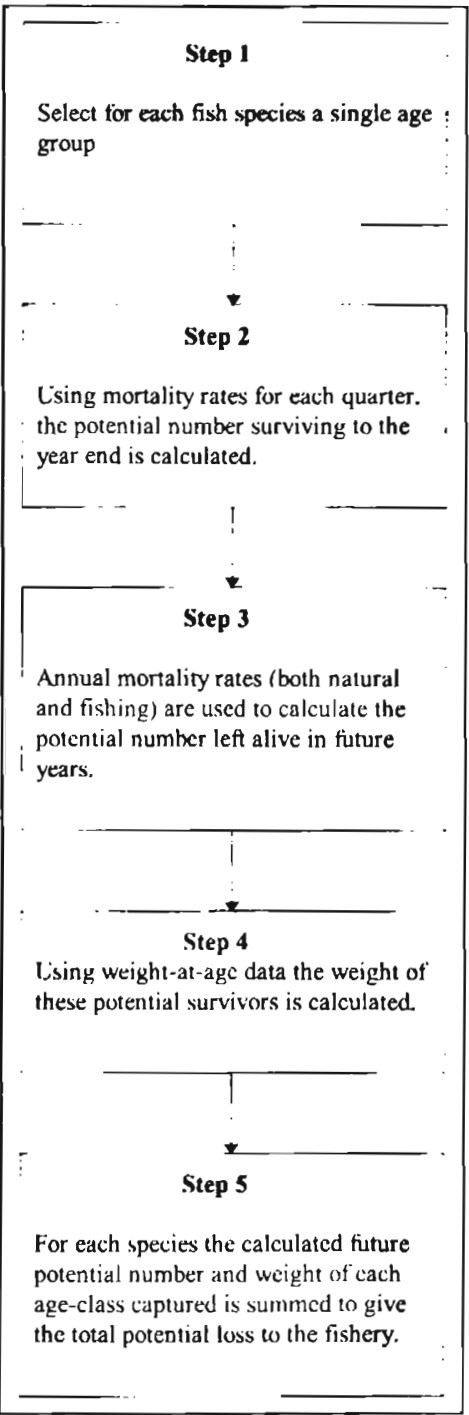

Fig. 2. - Estimating loss of future yield to the fishery (1981-2 study)

Fig. 2. - Estimation des futures pertes de la pêcherie dues aux captures de la centrale en 1981-2 The death of young fish below the minimum landing size can still affect the fishery by reducing future yield. Assessment of this effect is important as mosi of the fish captured by power stations are young and have no commercial value. The future value of fish is found in a manner similar to the calculation of future value of monetary assets under inflation. Using both natural and fishing mortality rates the future potential yield in numbers of an age-class can be caiculated as the proportion that would be expected to have survived. The calculation is undertaken in a number of steps. In Step 1 potential numbers surviving to the end of the year of capture if they had not been killed by the power station is calculated. Two simplifying assumptions were that all fish were caught at the mid-point of the quarter-ofcapture and also that fishing mortality over such a short period was assumed negligible. In Step 2, survival of power-station-captures al the end of successive whole years up to $8-10$ years old was calculated. The mortality rate applied to each year step included both natural and fishing mortality. To calculate the potential commercial loss, the number which would have survived to age $\boldsymbol{x}$ was multiplied by the average weight at age $\boldsymbol{x}$. By summating the future potential yields of each age-class captured by the power station, the total potential loss could be calculated. This total is the projected consequential loss to the fishery of commercial and undersized fish. and undersized fish. Table 3 then shows the weights of the commercialand under-sized fractions. The 'immediate loss' column gives weights of commercial-sized fish caught (total $4.6 \mathrm{t}$ ), while the 'consequential loss' columns (calculated as described in Figure 2) give an estimate of the potential realisable landings of the undersized fish, had the power station not been present (total $66 \mathrm{t}$ ). At 1981 market prices (at $1^{\text {st }}$ sale), these rep- 
resented a market value of $£ 2,800$ and $£ 28,000$ respectively; i.e., the market value of the undersized fish loss was potentially ten times larger than the face value of the catch, had it been sold at the time of capture.

As the North Sea is managed as a single fisheries unit, it was considered appropriate to look at the combined immediate and consequential loss figures in relation to North Sea spawning stock sizes as a whole. This comparison is made in Table 4, which shows that commercial fishing has between 1,000 and 100,000 times greater effect on stocks than Sizewell A Power Station.

\subsection{Conclusions from the 1981-2 Survey}

The report of the study (Turnpenny et al., 1983) came to the following conclusions:

- the commercial species of importance were cod, whiting, plaice, dab, sole and herring;

- the majority of the catch $(82 \%$ to $99 \%$ according to the species) was below the minimum commercial landing size;

- the annual catch at Sizewell A station of these species was less than that of a single, small and inefficient commercial trawler;

- the commercial fish stocks involved were not local, but covered large areas of the North Sea, so that any loss was born by the East Coast UK fishing industry as a whole, and to some extent by the international fleet operating in the North Sea, rather than by the industry local to Sizewell;

- the catch-rate would need to be several orders of magnitude larger for any effect on commercial fisheries to become detectable, given the large natural fluctuations in exploited fish populations.

\section{FISH IMPINGEMENT AT THE A STATION: THE 1992 UPDATE}

\subsection{Background}

In the early 1990's, with the imminent commissioning of Sizewell $B$ and a proposal to build an adjacent PWR, there was a need to update the 19812 assessment.

The operation of the $B$ station with a cooling water requirement of

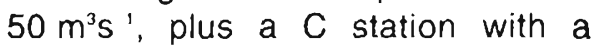
planned cooling water requirement of up to $100 \mathrm{~m}^{3} \mathrm{~s}^{-1}$, would have increased the potential water abstraction rate over that of the A station $\left(30.4 \mathrm{~m}^{3} \mathrm{~s}^{-1}\right)$ alone by a factor of up to 6 . At the time the then operator of Sizewell A and B (NEL) made a commitment to the planning authority that the $\mathrm{A}$ and $\mathrm{C}$ stations would not run concurrently, so a more likely scenario would have been the closure of the $A$ station and the concurrent operation of the $B$ and $C$ stations only (i.e. a 5 -fold increase in $\mathrm{CW}$ demand compared with the $\mathrm{A}$ station alone). In the event, the application to proceed with building Sizewell C was dropped. Neverthe- 
less, the study undertaken in 1992 provides a significant advance on earlier findings.

In the 1992 report (Turnpenny and Henderson, 1993), the implications of fish impingement for higher flow scenarios were considered in the form of a reappraisal of the 1981-2 study (Turnpenny et al. 1983). This re-appraisal took into account the following:

i) changes in the abundance indices, mortality coefficients and growth rates in North Sea fish stocks over the decade since the original analysis had been undertaken;

ii) more recent data on fish landings from the North Sea;

iii) the significance of intake design, positioning and water velocity on potential impingement rate;

iii) the potential effects of increased CW demand;

iv) the combined effects on adjacent fish stocks of the Sizewell power stations acting in concert with other UK East Coast power stations;

v) new information on the by-catch of juvenile fish in East Coast shrimp fisheries;

vi) any species not assessed in the 1981-2 study which were, in 1992, considered worthy of inclusion.

No new catch data from the power stations were collected for the 1992 study.

\subsection{The 1992 Analysis}

Year-class indices, fishing mortality rates and weight-at-age data were revised to reflect the most recent values then available from MAFF. Using these new values, the analyses described under the 1981-2 methodology were repeated.

Following consultation with MAFF one further species, the bass (Dicentrarchus labrax), was added to the list of commercial fish assessed. This fish was not included in the 1981 analysis because at that time the commercial catch on the East Coast was insignificant, but was thought from MAFF inquiries to have increased by 1992 .

The most important innovation was the use of the Equivalent Adult (EA) approach (Turnpenny, 1989a). This method gave an alternative to the potential future value approach adopted in the 1981 analysis for assessing the lost value to the fishery of young fish removed by the power stations. The EA method has the virtue of simplicity. It had also become a standard method in other fisheries evaluations and was used in a new version of the PISCES expert system for predictions of fish captures at other power station sites, therefore offering compatibility. As in the 1981-2 study, catch data were broken down into quarterly sets.

\subsubsection{The Equivalent Adult method}

The Equivalent Adult Value (EAV) is a mathematically derived value that 
measures the reproductive importance of an individual. The higher the EAV the greater the proportion of the parents' original reproductive effort the individual has come to represent. Thus an old juvenile, many of whose siblings have already died, will have a higher EAV than a recently born larva. Formally, it is defined as the proportion of the average lifetime fecundity of an adult that has just reached maturity that is required to replace a juvenile of known age. It is calculated as:

$$
\operatorname{EAV}(t)=1 / S(t) F(a)
$$

where $S(t)$ is the probability of survival to age $t$,

and $F(a)$ the average lifetime egg production.

$F(a)$ is calculated using:

$$
F(a)=\sum P(j) S(j) E(j) R(j),
$$

summated for age classes $j=1$ to $m$, where $a$ is the age at which $50 \%$ of the fish are mature,

$\mathrm{m}$, the number of age classes in the population,

$P(j)$, the proportion of females mature at age $\mathrm{j}$,

$S(j)$, the probability of survival from age a to j,

$E(j)$, average fecundity at age $j$, and $R(j)$, the proportion of females in age class $\mathrm{j}$.

The calculation procedure is detailed in Figure 3.

\subsubsection{The PISCES Expert System}

PISCES (Prediction of Inshore Saline Communities Expert System) is an expert system developed on behalf of NEL, for the prediction of fish impingement rates on coastal power stations located in Northern European waters. PISCES enabled the numerical abundance, seasonality, age composition, biomass and EAV to be predicted for any British estuarine or marine coastal power station, given information on latitude and longitude, salinity, substrate types and adjacent habitat types, and also on the power station pumping rates. It operates on two basic premises:

- that the presence or absence of a given species within a broad locality could be predicted from zoogeographic trends for that species (Henderson, 1989), and

- that the probability of finding a particular lifestage at a more precisely defined place within that broad locality would be determined by such conditions as salinity and substrate type (see e.g. Riley et al, 1981; Riley and Parnell, 1984).

The prediction of the actual numbers and biomass of each species was based on a calibration derived from a database held at Fawley of fish impingement data collected from British coastal power stations sites over 20 years.

\subsection{Results of the Updated Analysis of 1992}

\subsubsection{A Station Catch Rates}

Tables 5 and 6 compare figures estimated from the original 1981-2 analysis with those derived using the 
updated fisheries statistics and revised procedures in 1992.

The estimated immediate and consequential tonnages of commercially valuable fish removed by the A station are seen from Table 5 to differ in the 1992 analysis by way of a $50 \%$ increase in the estimated overall consequential loss. While there are minor

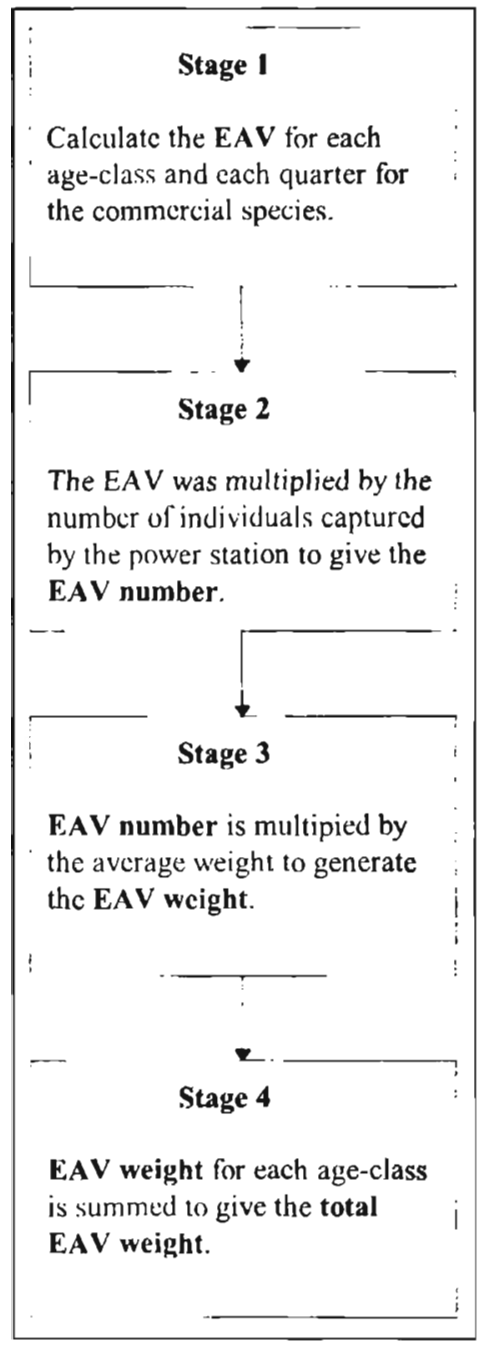

changes from species to species, as a result of variations in the fisheries statistics adopted and the revised methodology, by far the most significant cause of change was the increase in the herring fishery over the 10 year interval. Fish impingement rates as a proportion of North Sea stock sizes as a whole (Table 6) remained similarly small following the updated analysis.

The estimated combined loss of fish due to the East Coast power stations is presented in Table 7, which also gives their 1991 market values. The figures shown represented the worst possible case, in which all stations operated at maximum capacity simultaneously. In practice, such a situation would have been highly unlikely.

A total combined loss of 857 tonnes $y^{\prime}$ is indicated in this 'worst

Fig. 3. - The Equivalent Adult Procedure (1992 study)

Fig. 3. - Méthode d'évaluation de l'Equivalent Adulte" (1992)

The estimation of the EAV of the total catch for a species using the Sizewell data set required separate calculations for each species and age-class. The general scheme is shown in the flowchart.

The first stage in the calculation was to find the EAV for each age-class for each quarter. The calculations were undertaken under the assumption that the quarterly catch was all taken at the mid-point date.

In the second stage, the EAV values calculated for each age-class and quarter were multiplied by the total number of individuals captured over the quarter to give the EAV number.

At the third stage the EAV number was multiplied by the average weight at first maturity to generate the EAV weight.

Finally, the total EAV weight for the species was calculated by summing the EAV weight estimates for each age-class. 
Table 5. - 1992 study: estimated annual loss to the fishery of commercial-sized fish due to operation of Sizewell A power station: 1981-2 and 1992 estimates compared.

Tableau 5. - Estimation de la perte annuelle de la pêcherie commerciale due à Sizewell A : comparaison des résultats 1981-2 et 1992

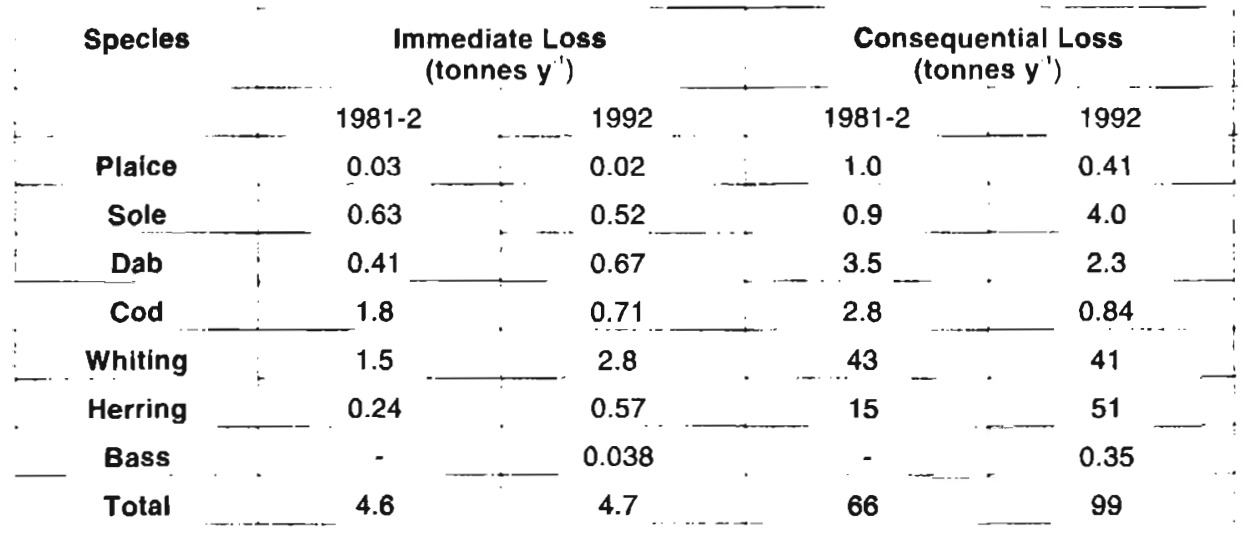

Table 6. - 1992 study: fish mortality due to impingement at Sizewell A power station as a percentage of north sea spawning stock numbers: 1981-2 and 1992 estimates compared.

Tableau 6. - Pourcentage de la mortalité des poissons entrainés dans la centrale de Sizewell A en 1981-2 et 1992, relativement au stock de reproducteurs en mer du nord.

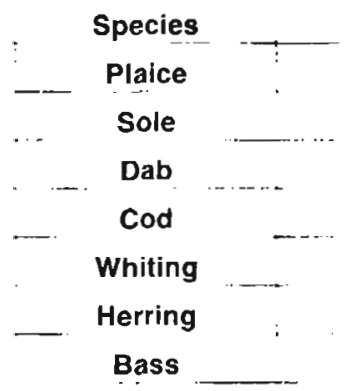

\section{Power Station Catch as a Percentage of Stock Size}

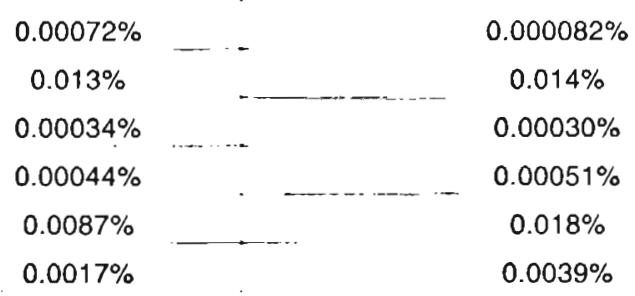

(stock size estimate for East Coast not available) case' scenario, with a (1992) market value of $£ 424,000$. This represented $13.9 \%$ of the tonnage and $4.8 \%$ of the value of UK landings from the Southern North Sea.

\subsubsection{East Coast Power Stations Combined}

PISCES predictions of fish catch for East Coast power stations other than Sizewell are given in Table 8. The numbers of fish are calculated by PISCES for the age at which 50\% would be expected to mature. Predicted catch weights are therefore computed by multiplying these numbers by the average weight at maturation. 
Table 7. - 1992 study: estimated annual equivalent adult tonnages and values of commercial fish species impinged at east coast power stations, compared with recorded landings by UK vessels in ICES area IVc (Southern North Sea).

Tableau 7. - Estimation du tonnage en équivalent adulte et de la valeur des espèces commerciales capturées par les centrales de la côte est, au regard des prises commerciales anglaises issues du secteur ICES IVc (sud de la mer du nord)

\begin{tabular}{|c|c|c|c|c|c|}
\hline Species & Impinged at Ea & Coast Power Stations & UK Landing & s tror & ES area I \\
\hline & Tonnes & £'000s & Tonnes & & $£^{\prime} 000 \mathrm{~s}$ \\
\hline Plaice & $11.1(1.4 \%)$ & $13.1(1.4 \%)$ & 789 & & 931 \\
\hline Sole & $35.1(4.8 \%)$ & $125.3(4.8 \%)$ & 735 & & 2624 \\
\hline Dab & $18.7(52 \%)$ & $11.4(52 \%)$ & 36 & & 22 \\
\hline Cod & $7.7(0.22 \%)$ & $10.1(0.22 \%)$ & 3513 & & 4602 \\
\hline Whiting & $345(180 \%)$ & $169(180 \%)$ & 189 & & 93 \\
\hline Herring & $435(50 \%)$ & $71.8(50 \%)$ & 865 & & 143 \\
\hline Bass & $3.44(6.5 \%)$ & $22.70(6.5 \%)$ & 53 & & 349.8 \\
\hline Totals & $857(14 \%)$ & $424(4.8 \%)$ & 6180 & - & 8764 \\
\hline
\end{tabular}

Table 8. - 1992 study: PISCES predictions of equivalent adult fish catches at other east coast power stations. (Units: numbers of individuals, except where otherwise indicated. Mean weights refer to weights at the age of $50 \%$ maturity for each species: see Turnpenny, 1989a).

Tableau 8. - Prévisions du modèle PISCES de la capture en équivalent adulte pour d'autres centrales de la côte est de l'Angleterre (1992)

$\begin{array}{lcccccccc}\text { Station } & \text { Plaice } & \text { Sole } & \text { Dab } & \text { Whiting } & \text { Cod } & \text { Herring } & \text { Bass } \\ \text { Hartlepool } & 1771 & 352 & 948 & 24,899 & 14 & 46,784 & 58 \\ \text { Bradwell } & 965 & 7480 & 3969 & 28,489 & 272 & 28,082 & 135 \\ \text { Isle of Grain } & 3696 & 4241 & 1978 & 51,977 & 29 & 97,661 & 347 \\ \text { Kingsnorth } & 3763 & 4317 & 2013 & 52,910 & 30 & 99,417 & 354 \\ \text { Tilbury } & 2490 & 2857 & 1333 & 35,013 & 20 & 65,790 & 234 \\ \text { West Thurrock } & 2490 & 2857 & 1333 & 35,013 & 20 & 65,790 & 234 \\ \text { Littlebrook } & 3930 & 3682 & 1718 & 45,130 & 25 & 84,796 & 302 \\ \text { Total Numbers } & 19,105 & 25,786 & 13,292 & 273,431 & 410 & 488,320 & 1664 \\ \text { Mean Wt kg } & \mathbf{0 . 4 2} & \mathbf{0 . 1 9 3} & \mathbf{0 . 1} & \mathbf{0 . 1 4 5} & 3.53 & \mathbf{0 . 1 1 3} & \mathbf{0 . 6 5} \\ \text { Total EA Wt tonnes } & \mathbf{8 . 0 2} & \mathbf{4 . 9 8} & \mathbf{1 . 3} & \mathbf{3 9 . 6} & \mathbf{1 . 4 5} & \mathbf{5 5 . 2} & \mathbf{1 . 0 8}\end{array}$

\subsection{Conclusions of the 1992 Study}

- Updating the 1981/2 analysis resulted in only minor changes in the estimated influence of the power stations on the fish stocks for species other than herring. A five-fold increase in the 'lost yield' of herring to the fishery was indicated for the A station, resulting from improved 
herring abundance in recent years as a result of stock protection measures imposed on the North Sea fishery, and also increased fishing for herring.

- Based on PISCES expert system predictions, East Coast power stations collectively account for a loss of fish valued at $£ 420,000$ annually. This equates to $4.8 \%$ of reported UK landings of the same species from the southern North Sea, which were valued at $£ 8.8$ million (1989-91 average). In practice, this estimate of the power station-related losses is greatly exaggerated, owing to the 'worst case' assumptions adopted.

\section{COMPARATIVE STUDIES OF FISHERIES EFFECTS: THE EAST COAST SHRIMP BY-CATCH STUDY}

\subsection{Background}

For the most part, the fishing mortality imposed by the fishing industry is aimed at adult members of the stocks, being subject to local, national and international regulations on minimum landing size. Power stations, on the other hand, tend to capture predominantly small fish, those which are unable to swim fast enough to escape from intake water currents: typically, the catch at a power station contains $80 \%$ or more of individuals of less than $20 \mathrm{~cm}$ standard length (Turnpenny, 1988a). Exceptions within the fishing industry are the whitebait fishery, which is aimed at juvenile fish not subject to landing size regulations (chiefly Sprattus sprattus). Another is the incidental catch (or 'by-catch') of juvenile fish which fail to pass through the meshes of trawls or which are caught within small-mesh coastal shrimp fisheries. Such fish are discarded and, whilst to the authors' knowledge no study of survivorship of discards has been published, it may be assumed that few survive the stresses of capture and handling.

Two approaches may be used to assess the significance of juvenile fish mortality caused by power stations. The first and simplest is to make a direct comparison of powerstation-induced mortality with captures of fish of comparable ageclasses taken in local fisheries. The principal difficulty in applying this approach has been the scarcity of data on the discard rates of juvenile fish from commercial fisheries. Symonds et al. (1985) conducted a study of the Morecambe Bay (Lancashire) shrimp fishery on pre-recruit sole and plaice and Turnpenny (1988b) was able to compare mortality from this source with catch rates at the adjacent Heysham I power station. The second approach is more complicated and requires evaluating the potential contribution of a juvenile fish to the commercial fishery. This approach was described in Section 3.

When the 1981-2 analysis was undertaken (Turnpenny et al., 1983), the authors felt that the catches of ju- 
Table 9. - By-catch study: catches of undersized fish in shrimp fisheries in the wash and off the german coast of the North Sea, compared to catches on Sizewell A power station (from Turnpenny ef al, 1983).

Tableau 9. - Comparaison des prises annexes des pêcheries de creveltes de la côte allemande de la mer du nord avec les captures de la centrale de Sizewell A (d'après Turnpenny et al, 1993)

\begin{tabular}{c} 
Specles \\
\multicolumn{3}{c}{ Plaice } \\
Sole \\
Dab \\
Whiting \\
Cod \\
No. of Samples \\
1 \\
1 \\
1 \\
2 \\
2 \\
2 \\
1 \\
0 \\
1 \\
1 \\
0
\end{tabular}

venile fish on the power station should be compared with discard rates of juveniles in inshore fisheries, as this represented a like-for-like comparison, which did not require any other scientific assumptions. An attempt to do this was made using published data on by-catch mortality in the Wash, and German North Sea coastal shrimp fisheries. The results are reproduced in Table 9. In all cases the catches of juvenile fish by the power station were orders of magnitude lower than the discard rates in these small-meshed shrimp fisheries.

The value of this comparison was considered compromised by the geo-

\section{Millions of Fish per Annum}

$\begin{array}{ccc}\text { The Wash, 1976-7 } & \text {. } & \text { German, } 1954-79 \\ 8.28 & . & 186 \\ 0.93 & . & 53 \\ 2.69 & . & 112 \\ 7.38 & . & 22 \\ 0.04 & . & 14\end{array}$

Month (89/90)

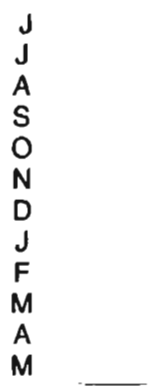

graphical remoteness of the two shrimp fishing areas from Sizewell. At the suggestion of the Ministry of Agriculture Fisheries and Food, the collection of by-catch samples from artisanal beam-trawl fisheries operating close to Sizewell was therefore undertaken. A survey was conducted for the CEGB by MAFF between June 1989 and April 1990. Local fishermen at Pakefield (Lowestoft) and Southwold were used to collect samples, under MAFF supervision. The analysis of these data was commissioned by the CEGB's successor at Sizewell, NEL. 


\subsection{Methods}

The field survey programme was designed by MAFF to reflect the seasonal pattern of exploitation in the fishery. The bulk of the effort was therefore expended in the autumn months, with reduced effort over the winter season. The actual sampling pattern used for both the Pakefield and Southwold sites was as follows:

Sampling was carried out by means of a $14 \mathrm{ft}(4.3 \mathrm{~m})$ beam trawl. At Pakefield, the standard tow was a $600 \mathrm{~m}$ length at $14 \mathrm{ft}(4.3 \mathrm{~m})$ depth and, at Southwold, a $720 \mathrm{~m}$ length at $12 \mathrm{ft}$ $(3.6 \mathrm{~m})$ depth. The sampling time (usually of 15 to 25 minutes), tidal state and water temperature were recorded.

Material from each sample was sorted to species of fish, and measurements of fish were taken, to the nearest $5 \mathrm{~mm}$. In samples containing large numbers of individuals, a subsample was taken and numbers were raised by the appropriate subsampling factor. Shrimps were measured volumetrically to the nearest half pint, so that quantities of fish could be calculated per tonne of shrimps landed in the commercial fishery.

A detailed analysis of the data was limited to the four prominent exploited fish species in the catch, namely sole, plaice, dab and whiting. The allocation of the catch to age-class followed a similar procedure to that used in the 1981-2 survey (Section 2).
The convention of dealing with quarterly total catches (JanuaryMarch, April-June, July-September, October-December) was also followed in this study to conform to the Equivalent Adult procedure described by Turnpenny (1988b) and used in the 1992 analysis.

For comparison with commercial fish landings, equivalent adult values (EAVs) for the fish within the shrimp catch were computed. The numbers per tonne were then raised by the recorded landings of shrimps for all East Coast ports between Boston, to the north, and Whitstable, to the south. The fish species investigated (sole, plaice, dab and whiting) are considered by MAFF to belong to stocks which extend along this entire stretch of the East Coast.

\subsection{Results}

Table 10 compares the numbers of juvenile fish and their EA tonnages for Sizewell A, East Coast power stations combined, and the estimated bycatch English East Coast shrimp fisheries.

The potential effects of Sizewell A are seen to be minor in comparison with levels of discards of these juveniles of these species within the East Coast shrimp fisheries. While these fish are returned to sea and may have an opportunity to survive, it is likely that the majority cannot survive the stress of being caught in a beam trawl and the subsequent handling. In the case of whiting, the numbers in pro- 
Table 10. - By-catch study: comparison of numbers of undersized fish and their equivalent adult weights impinged at Sizewell A power station, all East Coast power stations, and taken as by-catch in the english East Coast small-mesh shrimp fishery (Turnpenny, 1992).

Tableau 10. - Comparaison du nombre d'individus non commercialisables et de leur poids en équivalent adulte pour Sizewell $A$ et les autres centrales de la côte est.

\begin{tabular}{|c|c|c|c|c|}
\hline Species & Cause of Loss & $\begin{array}{c}\text { Numbers of } \\
\text { Undersized Fish } \\
\text { (millions) }\end{array}$ & $\begin{array}{c}\text { Equivalent Adult } \\
\text { Tonnage }\end{array}$ & $\begin{array}{l}\% \text { of Mean UK } \\
\text { Landings from } \\
\text { ICES area IVc }\end{array}$ \\
\hline Sole & $\begin{array}{l}\text { Sizewell A } \\
\text { E Coast Stations } \\
\text { Shrimp By-Catch }\end{array}$ & $\begin{array}{c}0.032 \\
0.122 \\
15.9\end{array}$ & $\begin{array}{l}4.02 \\
35.1 \\
346\end{array}$ & $\begin{array}{l}0.66 \\
4.8 \\
65\end{array}$ \\
\hline Plaice & $\begin{array}{l}\text { Sizewell A } \\
\text { E Coast Stations } \\
\text { Shrimp By-Catch }\end{array}$ & $\begin{array}{l}0.007 \\
0.040 \\
4.98\end{array}$ & $\begin{array}{l}0.41 \\
11.1 \\
133\end{array}$ & $\begin{array}{c}0.13 \\
1.4 \\
16.9\end{array}$ \\
\hline Dab & $\begin{array}{l}\text { Sizewell A } \\
\text { E Coast Stations } \\
\text { Shrimp By-Catch }\end{array}$ & $\begin{array}{l}0.021 \\
0.076 \\
3.36\end{array}$ & $\begin{array}{c}2.33 \\
18.7 \\
94\end{array}$ & $\begin{array}{l}2.6 \\
0.52 \\
261\end{array}$ \\
\hline Whiting & $\begin{array}{l}\text { Sizewell A } \\
\text { E Coast Stations } \\
\text { Shrimp By-Catch }\end{array}$ & $\begin{array}{l}0.422 \\
1.539 \\
11.0\end{array}$ & $\begin{array}{c}41 \\
345 \\
666\end{array}$ & $\begin{array}{l}22.5 \\
182 \\
352\end{array}$ \\
\hline
\end{tabular}

portion to commercial catches are high, owing to the fact that whiting are not a target species in the North Sea, consequently commercial exploitation rates are low.

\subsection{Conclusions of the By-Catch Study}

- No directly-measured fishing effort data were available for the fishery from which overall by-catch could be estimated. Instead, it was nec essary to use estimates of by-catch per tonne of shrimp landed and recorded shrimp landings to estimate total by-catch. These figures are believed to under-represent true landings figures and thus true bycatch values. No attempt is made by fisheries authorities to monitor shrimp landings other than at recording ports such as Lowestoft.

- In spite of the probable under-recording of shrimp landings, catches by the power station of individuals below the minimum commercial landing size (MCLS) of the three flatfish species, sole, plaice and dab were lower than the estimated by-catch in the shrimp fishery. Bycatches were between 5 to 23 times higher than the power station catch, according to species. Catches of undersized whiting were of the same order of magnitude for both the shrimp fishery and the power station intakes.

- Computed equivalent adult (EA) weights of fish above and below MCLS caught by the power station and in the shrimp fishery offer a better comparison of relative cap- 
ture rates, as they eliminate bias caused by differential seasonal fishing patterns. Using this method of analysis, capture rates of the three flatfish species by the power station were less than one third $(23-31 \%)$ of those due to the Lowestoft shrimp fishery, whereas whiting captures by the power station were twice the by-catch value.

- If pro-rata by-catches are assumed for other East Coast ports, from Boston (Lincolnshire) to Whitstable (Kent), then the equivalent adult bycatch amounts to $65 \%, 17 \%, 261 \%$ and $352 \%$, respectively, for sole, plaice, dab and whiting, of the southern North Sea (ICES Area IVc) UK landings of these species. A comparison with power station figures should take account of all power stations operating along this stretch of the coast.

\section{ICHTHYOPLANKTON SURVEY (1992-3)}

\subsection{Background}

Up to 1992 no studies had been undertaken on the ichthyoplankton (planktonic fish eggs/larvae) in the coastal waters in the vicinity of Sizewell. The MAFF had undertaken long-term studies of the plankton of the North Sea to the north of Norfolk, while the nearest continuous plankton recorder (CPR) runs were some 30 or more $\mathrm{km}$ offshore. The inshore waters around Sizewell were thought to be a nursery area for six species of commercial fish: plaice, sole, turbot (Scophthalmus maximus), sprat, herring and bass. All of these species have planktonic larvae, and all except the herring have planktonic eggs.

As planktonic fish are not retained by the CW intake screens, but pass through the condenser circuits, the degree of mortality due to the power station was not quantified during the 1981 survey. No previous studies on power station effects had considered the consequences on commercial fisheries of the combined actions of impingement and entrainment. Given this lack of information, NEL commissioned an assessment of ichthyoplankton entrainment, subsequently reported in Bamber et al, 1993. Sampling was undertaken both offshore and within the cooling water stream, to compare the planktonic fish stages (ichthyoplankton) available for capture to those actually caught.

\subsection{Methods}

The sampling programme comprised 12 monthly samples from 5 November 1992 until 20 October 1993. In the absence of any information on the seasonality of ichthyoplankton off the Suffolk coast, a regular, rather than randomised, sampling strategy was planned to cover all times of year equally.

Offshore plankton samples were collected using a Lowestoft Gulf III sampler with a mesh of $240 \mu \mathrm{m}$, fitted 
with a depressor. On each sampling trip, ten oblique haul samples were collected within a six-hour period from low water. Each haul was instigated 500 m upstream of the A station cooling-water intake, with the net being towed into the tide as it rose through the water column.

Power-station-entrained samples were collected from the cooling-water intake forebay, using a pump sampler; the sampler-tube was orientated vertically with its orifice maintained at 0.5 to $1 \mathrm{~m}$ below the water surface. The sampling mesh was again $240 \mu \mathrm{m}$. On each sampling trip, six one-hour samples were collected, again beginning at low water.

Both samplers were fitted with flow-meters to allow measurement of the sampled volumes, thence crosscalibration of the quantitative samples. These meters were calibrated in the laboratory by pumping a known volume of water (2000 I) through the samplers. Total sample volume for each trip for either the forebay or offshore was approximately $300 \mathrm{~m}^{3}$.

Samples were preserved in formalin and sorted in the laboratory. All fish eggs and larvae per sample were counted and identified where practical under the binocular microscope, using a key by Russell (1976); only the species of potential commercial or conservation concern were identified to species level.

The quantitative data were converted to figures representative of recruitment to adult fish stocks using the Equivalent Adult method of Turnpenny (1989a).

\subsection{Results}

The main findings for the commercially important species are summarised in Table 11, which lists the estimated numbers of eggs and larvae killed during passage through Sizewell A, allowing for the estimated survival of some individuals. The entrainment mortality rates were determined by the separate experimental study described in Section 6.

\subsection{Conclusions}

- Sizewell Power Station entrains significant numbers of the planktonic stages of some commercially important fish, viz. eggs of sole and sprat and larvae of clupeids and plaice.

- Of the other species considered to be potentially at risk, bass were incidental (as eggs) and no turbot eggs or larvae were recorded. Larvae of edible crabs were also entrained in large numbers but not those of lobster.

- The densities entrained are lower than those existing in the typical local water column for surface distributed plankton and higher for those distributed nearer the bottom; this difference is attributed to the intake being near the sea-bed and capped to minimise the drawdown of surface waters. 
Table 11. - Summary of equivalent adult analysis for commercial species of ichthyoplankton entrained annually at Sizewell A power station (numbers of individuals, except where stated).

Tableau 11. - Estimation en équivalent adulte de l'ichthyoplankton des espèces commerciales entrainés dans la centrale de Sizewell A (en nombre d'individus, sauf précision particulière).

\begin{tabular}{|c|c|c|c|c|c|}
\hline Species & $\begin{array}{c}\text { Sole } \\
\text { (eggs) }\end{array}$ & & $\begin{array}{l}\text { Herring } \\
\text { (larvae) }\end{array}$ & & $\begin{array}{c}\text { Plaice } \\
\text { (larvae) }\end{array}$ \\
\hline Months of Entrainment & $\begin{array}{l}\text { March- } \\
\text { June }\end{array}$ & Jan & June & July & June \\
\hline Entrainment Mortallty Rate & $20 \%$ & : & $100 \%$ & & $75 \%$ \\
\hline $\begin{array}{l}\text { Total Mortality (individuals } \\
\text { /year) }\end{array}$ & $4.1 \times 10^{9}$ & $4.91 \times 10^{5}$ & $4.19 \times 10^{7}$ & $1.80 \times 10^{\circ}$ & $2.92 \times 10^{6}$ \\
\hline Assumed Age of Fish (days) ! & 3 & 65 & 40 & 56 & 107 \\
\hline Equivalent Adult Factor & $2.47 \times 10^{-5}$ & $1.84 \times 10^{-2}$ & $2.41 \times 10^{-2}$ & $6.89 \times 10^{-2}$ & $2.31 \times 10^{-2}$ \\
\hline $\begin{array}{l}\text { Equivalent Adult Number } \\
\text { (individuals /year) }\end{array}$ & 101,280 & 9,016 & 101,098 & 12,411 & 6,731 \\
\hline $\begin{array}{l}\text { Equivalent Adult Wt. } \\
\text { (tonnes/year) }\end{array}$ & 19.6 & 1.0 & 11.4 & 1.4 & 2.34 \\
\hline
\end{tabular}

- Calculation of the equivalent adult value of the entrainment losses of these planktonic stages raised the estimates of the economic loss to the regional fishery (ICES Sea Area IVc) for Sizewell A station from $£ 45,610$ (for impingement losses alone) to $£ 120,406$ (calculated at 1991 prices).

\section{SURVIVAL RATES OF ENTRAINED ORGANISMS (LABORATORY STUDY)}

\subsection{Background}

The passage of material within the water body through a power-station cooling water system is known as entrainment. Entrained material includes holoplanktonic organisms (permanent members of the plankton, such as copepods, diatoms and bacteria) and meroplanktonic organisms (temporary members of the plankton, such as juvenile shrimps and the planktonic eggs and larvae of invertebrates and fish).

In the past the effects of entrainment passage, with its extremes of pressure, temperature and biocide concentration, on planktonic organisms have been studied directly at power stations by looking at the survival of those organisms available or detectable (e.g. Dempsey, 1988). Such studies, of necessity, were only able to test those organisms which were serendipitously available, and only observe the effects of the totality of entrainment, although Coughlan \& Davis (1981) were able to vary the chlorine dosing levels in their study of entrained whole plankton at Fawley Power Station. 


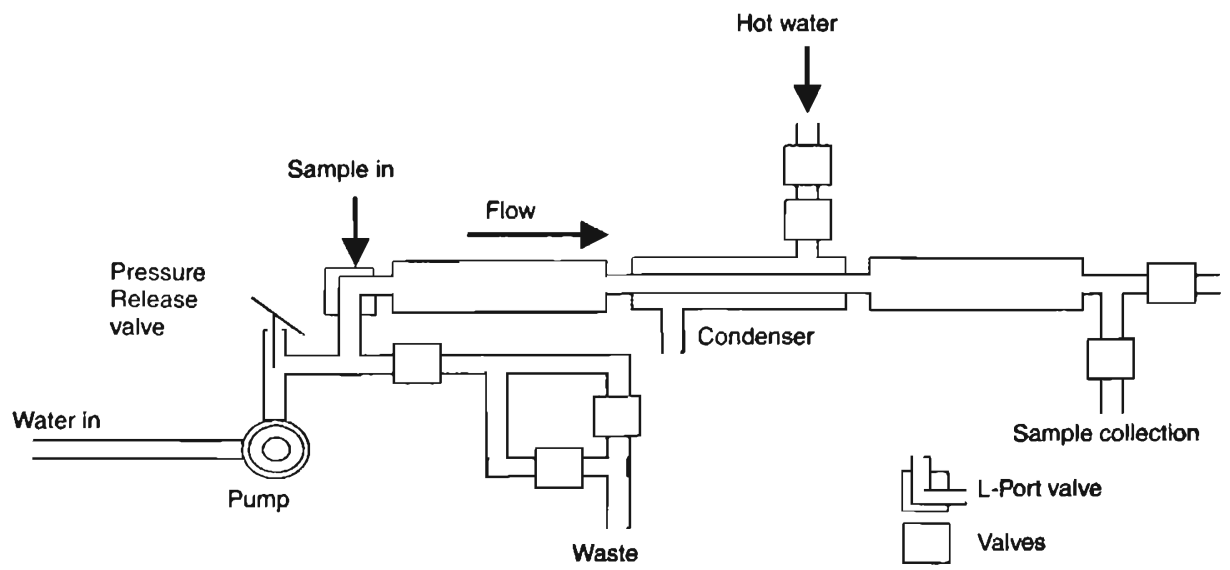

Fig. 4. - Schematic Diagram of the Entrainment Mimic Unit (EMU).

Fig. 4. - Schéma du module de simulation d'entraînement

Specific studies on the differential effects of entrainment stresses are more ideally undertaken under controlled laboratory conditions. Such conditions allow a guarantee of the presence of test organisms in adequate numbers and the control of the entrainment characteristics in order to determine more precisely which (if any) of these may be responsible for any deleterious effects. Such a study was commissioned by NEL.

\subsection{Methods}

An apparatus (the Entrainment Mimic Unit, EMU) was constructed to mimic the conditions of entrainment passage through the cooling-water system of a coastal power station (Bamber \& Seaby, 1993). The core of the EMU is a power station condenser tube through which heated water is passed (Figure 4).

A number of marine organisms having planktonic life stages were introduced into the apparatus, in groups of approximately twenty individuals at a time. These groups were then exposed to a regime of pressure change, chlorine dose and heat that simulated their possible experience following entrainment. They were also passed along the condenser tube simulating the conditions that could cause mechanical damage. The conditions selected were based on specified design values for the Sizewell B CW circuit. Following exposure, the larvae were collected and examined after 6,24 and 48 hours and their condition assessed. 


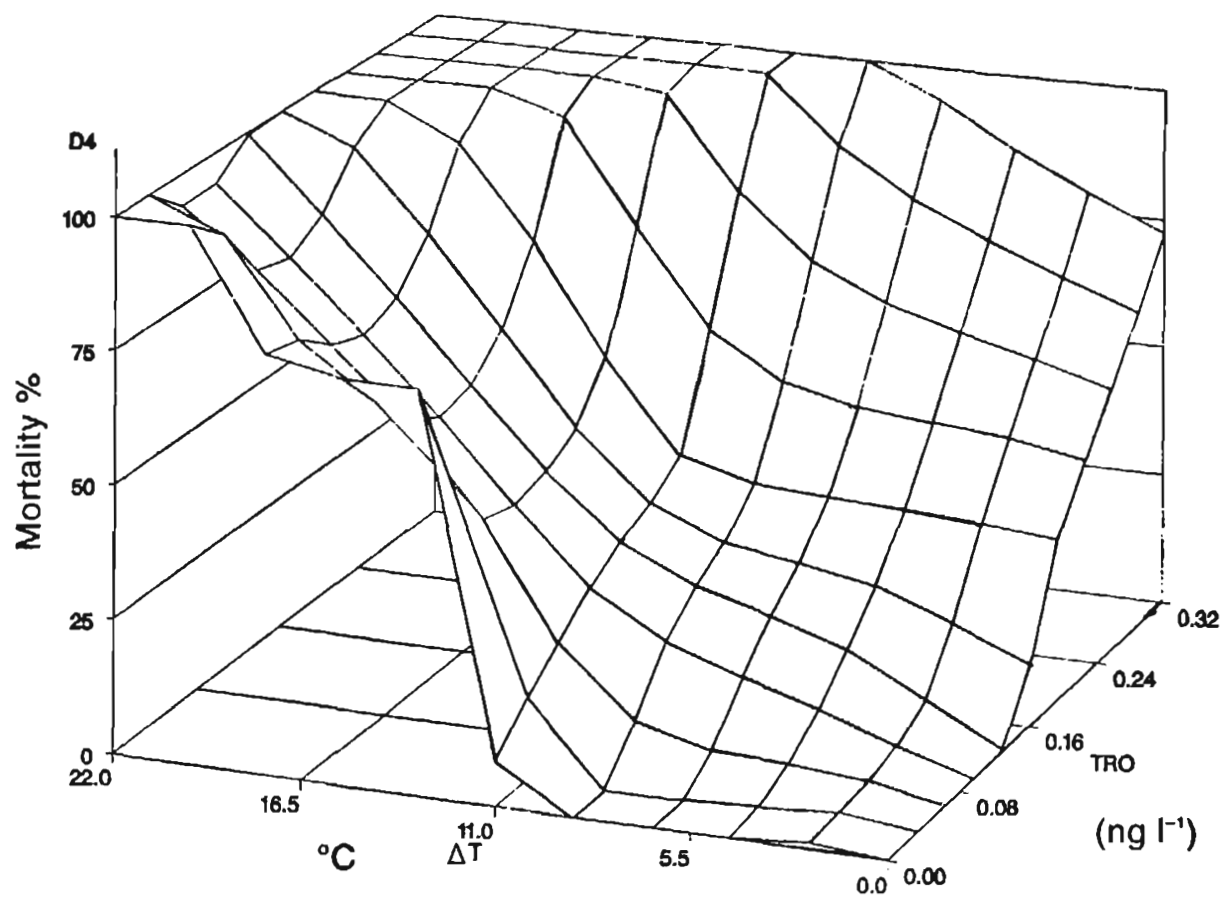

Fig. 5. - Example of an EMU Test: 3D Surface Plot of Mean $48 \mathrm{~h}$ Mortality (PNR) of Shrimp larvae in Relation to Temperature Increase ( $(t)$ and Total Residual Oxidant (TRO).

Fig. 5. - Résultats de la mortalité à $48 \mathrm{~h}$ d'un test de simulation d'entrainement sur des crevettes en relation avec un échauffement et une teneur en oxydant résiduel.

\subsection{Results}

The results for planktonic stages of sole, turbot (Psetta maxima (L.)), Pacific oyster (Crassostrea gigas Thunberg), bass, lobster (Homarus gammarus (L.)), edible mussel (Mytilus edulis L.) and the copepod (Acartia tonsa Dana) are detailed in a series of reports (Bamber and Seaby 1993; 1994 a, b, c, d; 1995 a,b; Bamber et al. 1994). C. gigas is a non-indigenous species to the UK but was selected as a convenient bivalve representative. A typical example of the type of results obtained is shown in Figure 5. This shows a response surface for the effects of temperature change and chlorine exposure at different concentrations. Response surfaces of this general form were produced for each of the species listed above.

\subsection{Conclusions}

\section{For sole}

* Mechanical stresses during entrainment had no adverse effects on entrained sole postlarvae. 
* Pressure changes similar to those that would be experienced during entrainment likewise had no adverse effect on either postlarvae or eggs.

* Chlorine exposure at levels typically applied by UK coastal power stations caused significant mortalities amongst sole postlarvae and but had no adverse effect on eggs.

* A rise in temperature equivalent to that which would be experienced during entrainment caused significant mortality amongst sole postlarvae and significant damage to eggs.

* Ternperature and chlorine acted synergistically so that together they were more lethal than the simple sum of their effects would predict. At normal power station operational levels predicted the mortality of entrained sole would be of the order of $35 \%$.

\section{For turbot.}

* The mechanical stresses of entrainment resulted in damage to some $70 \%$ of entrained turbot larvae, but no damage to the eggs.

* Chlorine exposure at levels typically applied by UK coastal power stations had no adverse effects on entrained eggs.

* Pressure changes similar to those that would be experienced during entrainment appeared to reduce the hatching rate of eggs by about $3 \%$.

* A rise in temperature equivalent to that which would be experienced during entrainment caused 25 to
$60 \%$ of eggs to lose buoyancy, with an implied hatching of up to 20 to $25 \%$ for sinking eggs.

For bass:

* Neither mechanical stresses nor pressure conditions typical of entrainment had any adverse effect upon eggs and larvae of bass.

- Bass eggs were not harmed by the chlorine levels typical of entrainment, but levels $\geq 0.2 \mathrm{ppm}$ caused significant mortality (30 to $70 \%$ ) amongst larvae.

* Temperature conditions that would be expected during entrainment passage at UK power stations caused significant reductions in egg hatching rates and larval survival rates.

* A combination of elevated temperature and chlorine exposure typical of that found during entrainment UK power stations when chlorine is being applied (for antifouling control purposes) would cause 40 to $46 \%$ mortality of entrained bass eggs and larvae.

For shrimp larvae:

* Chlorine at levels typically applied by UK coastal power stations caused significant mortalities of entrained shrimp larvae after 48 hours, in the order of 30 to $40 \%$.

* Pressure changes equivalent to those that would be experienced during entrainment had no significant adverse effects on entrained shrimp larvae.

* A rise in temperature equivalent to that which would be experienced during entrainment had adverse 
effects on entrained shrimp larvae, possibly by enhancing the sensitivity of the larvae to chlorine.

- The mechanical stresses of entrainment had no significant adverse effects on entrained shrimp larvae.

For lobster larvae:

* Typical temperature, chlorine and pressure flux conditions experienced during entrainment passage at UK power stations were not harmful to larvae of lobster. Significant thermally-related mortalities occurred only at increments of $\left(12.5^{\circ} \mathrm{C}\right.$ above the ambient temperature.

* The larvae were sensitive to the mechanical stresses of entrainment (shear stresses and abrasion) that resulted in $7.7 \%$ mortality during experiments.

* The overall entrainment mortality for lobster larvae at UK power stations would therefore be expected to be below $8 \%$.

\section{COMPARISON OF THE A AND B STATION IMPINGEMENT RATES (1994)}

\subsection{Background}

NEL, as operator of the Sizewell stations, agreed with MAFF that on commissioning at Sizewell $B$ the fish impingement rates at the $A$ and $B$ stations would be compared.

The maximum cooling water flow of the A station is $30.4 \mathrm{~m}^{3} \mathrm{~s}^{-1}$, and the average used during 1994 was $25.8 \mathrm{~m}^{3} \mathrm{~s}$ ', compared with a planned normal operating flow of $50 \mathrm{~m}^{3} \mathrm{~s}^{-1}$ for the $\mathrm{B}$ station. Assuming the fish were equally vulnerable at both intakes, the pro rata increase in fish catch rate for the $\mathrm{B}$ station would have been expected to be nearly twolold. However, in the design of the cooling water intake system for the B station, a number of differences and improvements were incorporated, which were expected to reduce the relative catch rates. These included:

(i) Adoption of a capped intake design. Although this feature was intended primarily to ensure selective withdrawal of deeper, cooler water, and to reduce the likelihood of surface vortex formation, capped intakes have the potential benefit to fish of eliminating vertical velocity components which fish are ill-equipped to swim against. Trials in the United States (US) have shown that ingress of some species, especially pelagic ones (e.g. sprat and herring), can be substantially reduced by the fitting of intake caps (also known as velocity caps) (see Turnpenny, 1988a).

(ii) Adoption of a $50 \mathrm{~cm} \mathrm{~s}^{-1}$ design approach velocity. This design velocity, measured at the trash rack surface on the offshore intake structures under slack-water tidal conditions, was adopted to conform to US recommendations for capped intake structures (see Turnpenny, 1988a). In practice, the relevance of it to Sizewell is questionable:

- firstly, the species and water temperatures (both of which affect swim- 
ming performance and hence the ability of fish to escape intake currents) differ from those in Southern California where the original work was carried out;

- secondly, this velocity would apply only to slack water conditions, with water velocities increasing markedly as tidal cross-flows developed (see Turnpenny, 1988a, for a full explanation, and Turnpenny and Henderson, 1992, for a more detailed treatment of catch rate versus approach velocity relationships).

Nevertheless, the reduced velocities around the slack water period might confer some advantage on fish.

(iii) Location of the intakes further offshore. The Sizewell shoreline forms part of a nationally important nursery area for flatfish species such as sole, plaice and dab. The highest densities of juvenile flatfishes are to be found close inshore. Hence, by placing the intakes further offshore (some $600 \mathrm{~m}$ offshore, of $300 \mathrm{~m}$ for the A station), some reduction in the catch of juvenile flatfish would be expected. Again, the primary reason for locating the intakes further offshore was to obtain cooler water.

(iv) Elimination of superstructures. Elaborate superstructures, such as are present on the A station, form artificial reefs which attract fish. The elimination of superstructures on the B station intakes should have reduced this possibility.

(v) Incorporation of a fish return system. As many fish and shrimps which enter the cooling water system are not harmed by their treatment, up until the point where they enter the wash-water system and trash baskets, provision was made in the $B$ station design to remove them from the intake drum screens and return them to the sea via the cooling water seal pit and outfall. The potential benefits of this approach are discussed by Turnpenny (1992b). This measure was expected to reduce the overall ecological impact of the cooling water abstraction, but its use was subject to approval by the then National Rivers Authority (NRA) following demonstration trials to assess any nuisance caused by the incidental discharge of other debris screened from the water by the screens.

None of these potential benefits could be quantified prior to the B station cooling water plant becoming operational, consequently the 'worst case' assumptions had to be adopted in both the 1983 and 1992 analyses of the predicted fish captures by the $B$ and $\mathrm{C}$ stations respectively.

The B station cooling water system began commissioning trials for a limited period in early 1994, providing the opportunity to make direct comparisons of the $A$ and $B$ station impingement rates. Surveys on both stations were initiated in mid-March 1994 and continued into early May. The sampling programme was designed to resolve statistically significant differences in catch-rates between the two stations as far as was possible within constraints imposed by species seasonality. 
In addition to measuring catchrates for the original six commercial species listed above, the scope was enlarged to include bass, the brown shrimp and a quantification of weed and anthropogenic debris. The latter was included as part of a joint exercise between NEL and the NRA to assess the effect of operating the fish return system on debris accumulation on the adjacent shore.

\subsection{Methods}

The sampling period was chosen on the basis of a review of the 1981-2 survey data (Turnpenny et al., 1983). The period chosen was at a time of year when large numbers of fish would be captured.

Sampling of the cooling water screens was undertaken only when both stations were operating simultaneously. On the A station, this meant that three or four (of four available) cooling water pumps were running, consistent with the earlier 1981-2 survey. On the $B$ station, three (of four available) pumps were required to be running, as was to become the normal operating practice for the station.

Although all catches were to be converted to a standard unit of cooling water flow, no effective correction can be made for the effect on intake velocity of altering the pumped flow, hence this effect must be excluded by adopting standardised running conditions.

Sampling and recording procedures were consistent with those used in the 1981-2 survey. For the seven important commercial species (including bass), hourly samples were counted and weighed by species, and samples were taken periodically to obtain length distributions (standard length, to the nearest $5 \mathrm{~mm}$ ).

For other species, as a minimum, numbers by species only were recorded. Shrimps were sorted and weighed in sample batches and, being of relatively uniform size, hourly numbers could be derived from mean weight data.

The remainder of material after fish and shrimps had been removed was divided into the convenient categories (whiteweed, mussel shell, plastics, etc.) and recorded.

All the daily figures were standardised to a flow rate of $1 \mathrm{~m}^{3} \mathrm{~s}^{-1}$.

A limited programme of contemporaneous offshore trawl sampling was carried out, to compare fish densities along the respective depth contours of the $A$ and $B$ intakes. This was to enable any differences in catch rates to be apportioned to intake placement effects versus intake design effects.

Two parallel sampling methods were adopted. To sample flatfish and other epibenthic species, a $3 \mathrm{~m}$ beam trawl was used; for other species, a small otter trawl was deployed. Both types of net were fitted with graduated meshes, leading to a $1 \mathrm{~cm}$ (halfmesh) cod-end.

Sample tows were made over nominal 20-30 minute hauls, along the depth contours of each intake. 
Table 12. - A and B station comparison: mean daily catch rates of fish per cubic metre of water abstracted.

Note: Values given are population geometric means and (in parentheses) standard deviations (i.e. geometric variance). The statistical significance of $\mathrm{A}: \mathrm{B}$ station differences are tested using a paired ' $\mathrm{t}$ '-test. comparing pairs of days for each station; asterisks indicate significance level: " $p<05$ " $p<01$ "** $p<005$.

Tableau 12. - Comparaison des prises moyennes journalieres par $m^{3}$ d'eau de refroidissement des tranches $A$ et $B$ de la centrale de Sizewell.

\begin{tabular}{|c|c|c|c|c|c|}
\hline \multirow[b]{2}{*}{ Species } & \multicolumn{2}{|c|}{ A Station } & \multicolumn{2}{|c|}{ B Station } & \multirow{2}{*}{$\begin{array}{l}\text { B Station } \\
\text { No. as \% of } \\
\text { A Station }\end{array}$} \\
\hline & Number & Weight (g) & Number & Weight (g) & \\
\hline Sole & $14.2(1.11)$ & $622(1.16)$ & $\begin{array}{l}8.92(1.09) \\
t=8.13^{* * *}\end{array}$ & $\begin{array}{c}490(1.11) \\
t=2.98^{\cdots}\end{array}$ & 63 \\
\hline Dab & $0.39(1.48)$ & $9.86(2.15)$ & $\begin{array}{l}0.18(1.53) \\
t=3.75 \cdots *\end{array}$ & $\begin{array}{c}4.80(2.73) \\
t=2.39^{*}\end{array}$ & 46 \\
\hline Plaice & $0.63(1.39)$ & $4.83(1.70)$ & $\begin{array}{l}0.34(1.28) \\
t=3.68^{* * *}\end{array}$ & $\begin{array}{c}3.60(1.56) \\
t=1.18 \mathrm{~ns}\end{array}$ & 54 \\
\hline Herring & $0.38(1.57)$ & $22.5(2.67)$ & $\begin{array}{c}0.28(1.73) \\
t=0.60 \mathrm{~ns}\end{array}$ & $\begin{array}{c}16.4((1.50) \\
t=2.33^{\circ}\end{array}$ & 74 \\
\hline Whiting & $29.3(1.05)$ & $1044(1.24)$ & $\begin{array}{c}23.2(1.48) \\
t=1.51 \mathrm{~ns}\end{array}$ & $\begin{array}{l}865(4.37) \\
t=0.65 \mathrm{~ns}\end{array}$ & 79 \\
\hline Cod & $1.30(1.77)$ & $208(0.09)$ & $\begin{array}{l}1.25(2.46) \\
t=0.31 \mathrm{~ns}\end{array}$ & $\begin{array}{l}207(3.34) \\
t=-0.24 \mathrm{~ns}\end{array}$ & 99 \\
\hline Bass & $0.89(2.60)$ & $156(2.66)$ & $\begin{array}{c}0.81(3.18) \\
t=2.52^{* *}\end{array}$ & $\begin{array}{c}104(18.52) \\
t=0.65 \mathrm{~ns}\end{array}$ & 91 \\
\hline Sprats & $92.9(1.60)$ & $1096(1.53)$ & $\begin{array}{l}35.2(1.60) \\
z=5.10^{\cdots}\end{array}$ & $\begin{array}{l}451(1.64) \\
t=11.74^{\cdots \cdots}\end{array}$ & 38 \\
\hline All Others & $28.3(1.28)$ & $604(1.25)$ & $\begin{array}{l}13.8(1.09) \\
t=3.33^{* * *}\end{array}$ & $\begin{array}{l}191(1.27) \\
t=2.64^{* * *}\end{array}$ & 49 \\
\hline
\end{tabular}

Five hauls were made by each method per intake line on four separate dates, spread over the survey period. The sampling pattern was carried out to ensure that there was no tidal or diurnal bias to one intake or the other, by interlacing the hauls between intakes.

Samples were treated as per the intake screen samples.

\subsection{Results}

Catch rates for the $A$ and $B$ stations are compared in Table 12. For all species, catch rates per unit of $\mathrm{CW}$ flow were lower on the B station, although for certain species the difference was not significant at the $p=0.05$ level. Over all species, a $50 \%$ reduction per unit flow was recorded.

(3) Sprat numbers were not recorded on all days. the overall totals being calculated from weight records and average weight data. It was not possible, therefore, to use paired 't'-tests for sprat numbers and the ' $z$ ' statistic (Fowler and Cohen, 1990, pp 174-5) was used instead. 


\subsection{Conclusions from the A and B Station Comparison}

- Catches of all the commercially important species per unit of cooling water flow were lower on the $B$ station than on the A station. The $B$ station catch rates, expressed as a percentage value of those for the $A$ station, were as follows:

$\begin{array}{ll}\text { Sole } & 63 \% \\ \text { Dab } & 46 \% \\ \text { Plaice } & 54 \% \\ \text { Herring } & 74 \% \\ \text { Whiting } & 79 \% \\ \text { Cod } & 99 \% \\ \text { Bass } & 91 \% \\ \text { Sprat } & 38 \%\end{array}$

For the remaining fish species caught, B station catches averaged $49 \%$ of those for the A station. The modifications to the intake design and siting have therefore had a significant effect on fish catches, reducing overall numbers by about half.

- The factors responsible for reducing catch rates cannot be ascribed unequivocally to individual intake improvements, though the adoption of a capped design for the $B$ station is likely to be the predominant one, especially for those fish such as sprat and herring which occupy the upper water column. Elsewhere, in the USA, capped intake designs have been shown to be capable of reducing the catch of pelagic fish by up to $90 \%$ (Turnpenny, 1988). Positioning the intake further off- shore should also have reduced the risk to inshore species, particularly young flatfish in the surf zone. This fish distributional difference was not fully born out by the trawling surveys, which indicated essentially similar fish communities on the two stations' intake depth contours, but 0-group sole were less common on the B station's intake line and in its screen catches.

- Quantities of shrimps per unit of cooling water flow were virtually identical for both stations (see Table 13).

- Combining these results with the successful findings of the fish return system trials (see below) indicates that, despite the larger flow rate of the $B$ station (about twice that of the A station), the overall impact on fish and shrimps, with the fish return system in operation, is less than that of the A station.

\section{SURVIVAL THROUGH THE FISH RETURN SYSTEM (1994)}

\subsection{Background}

Fish caught upon the $\mathrm{CW}$ screens of a coastal power station have, in their capture, been subject to a number of stresses. Initially drawn into the $\mathrm{CW}$ system through the intake, they can become subject to mechanical, shear and pressure stresses as they are swept along the culvert. Being drawn into the turbulent forebay and 
Table 13. - Mean daily catch rates of invertebrates and other materials per cubic metre of water abstracted by the $A$ and $B$ stations

Note: Values given are arithmetic means and (where given) standard deviations (shown in brackets). The statistical significance of $A: B$ Station differences are tested using a ' $z$ '-test; asterisks indicate significance level: ${ }^{*} p<0.05^{* *} p<0.01^{* * *} p<0.005$.

Tableau 13. - Captures moyennes journalières d'invertébrés et d'autres matériaux par $\mathrm{m}^{3} \mathrm{~d}^{\prime} e a u$ de refroidissement des tranches $A$ et $B$ de la centrale de Sizewell.

\begin{tabular}{|c|c|c|c|c|c|}
\hline \multirow{2}{*}{$\begin{array}{c}\text { Species } \\
\text { or Material }\end{array}$} & \multicolumn{2}{|c|}{ A station } & \multicolumn{2}{|c|}{ B station } & \multirow{2}{*}{$\begin{array}{c}\text { B No. as } \% \\
\text { of } A^{4}\end{array}$} \\
\hline & Number & Weight (g) & Number & Weight (g) & \\
\hline $\begin{array}{l}\text { Crangon } \\
\text { crangon }\end{array}$ & $159(8.1)$ & $293(212)$ & $\begin{array}{l}163(104) \\
z=0.23 \mathrm{~ns}\end{array}$ & $\begin{array}{l}300(192) \\
z=0.14 \mathrm{~ns}\end{array}$ & 102 \\
\hline $\begin{array}{l}\text { Other Crus- } \\
\text { tacea }\end{array}$ & $8.86(3.80)$ & $62.3(27.5)$ & $\begin{array}{c}4.39(2.52) \\
z=5.9^{\star \star \star}\end{array}$ & $\begin{array}{l}26.3(32.7) \\
z=5.05^{* \star *}\end{array}$ & 42 \\
\hline Ctenophora & $\cdot$ & 2148 & - & 2097 & 98 \\
\hline Mussels & $0.25(0.45)$ & 2.77 & 0 & 0 & - \\
\hline Whiteweed & - & 386 & - & 539 & 140 \\
\hline $\begin{array}{l}\text { Other Inver- } \\
\text { tebrates }\end{array}$ & - & 1.87 & - & 18.3 & 984 \\
\hline $\begin{array}{l}\text { Mussel } \\
\text { Shell }\end{array}$ & $\cdots$ & 64 & - & 0 & - \\
\hline Other Shell & - & 45 & $\therefore$ & 0 & $\cdot$ \\
\hline $\begin{array}{l}\text { Plastic } \\
\text { Sheet }^{t}\end{array}$ & - & 2.6 & - & 4.0 & 152 \\
\hline String & $\cdot$ & 10.2 & $\cdot$ & 7.4 & 73 \\
\hline Wood & - & 126 & - & 60 & 48 \\
\hline Algae & - & 457 & - & 24.7 & 5.4 \\
\hline Other debris & - & 93 & - & 711 & 766 \\
\hline
\end{tabular}

drumscreen well area, some of these stresses continue, while others, such as pressure, are reversed. The screens are low-pressure filtration systems and fish tend to be lifted clear of the water somewhat spent. Mechanical stresses at this point are reduced if the elevator ledges on the screens act as scoops, holding the fish in water. Once the ledges reach the spray wash system, the catch is flushed into backwash troughs, again with the risk of physical trauma, and thence into gullies which traditionally lead to trash baskets or skips.

To reduce the environmental impact of impingement and the need for solid waste disposal during the opera-

(4) or by weight or area, as applicable, where numbers were not recorded

(5) A4 sheet equivalents, by area 
tion of Sizewell B, a fish and trash return system was incorporated, allowing impinged material to be rapidly transferred back to sea. A review was first undertaken to assess the merits of such systems where they had been used elsewhere (mainly in the USA and France), and to draw together design criteria. It was concluded that a simple system would be effective, and the system at Sizewell was designed to achieve this. It incorporates the following features:

- enlarged elevator ledges ('fish buckets') on the drum screens, so that fish are held in water during lifting from the screenwells towards the washwater system;

- maintenance of the higher-speed rotation setting for the drum screens, to reduce the lifting time;

- maintenance of the higher backwash water flow rate setting, to transfer the catch off the screens most effectively; this backwash spray pressure of bar to reduce hydraulic shear damage to fish;

- half-round section, smooth-surfaced wash-water gullies designed to minimise surface area:volume so as to avoid abrasion damage to fish;

- swept bends ( $3 \mathrm{~m}$ radius) rather than sharp corners, to reduce turbulence and maintain laminar flow;

- a discharge from the final gully directly into the $\mathrm{CW}$ seal pit, exiting through a half-round section chute, from whence material is carried back to sea;
- an alternative discharge route into trash baskets for use at times of heavy ingress.

During normal operation the effluent in which the material, including fish and shrimp, is returned to sea is approximately $10^{\circ} \mathrm{C}$ above ambient, a result of passage through the condensers. The effluent in the outfall surge shaft is highly turbulent, so that fish are not always carried immediately into the outfall culvert; the estimated average retention time in the seal pit is 5 minutes. The fish are then carried down the outfall culvert, taking another 5 minutes. Once released back into the sea, they will spend a variable time in the discharge plume.

During the precommissioning trials of Sizewell B, an experimental protocol was established to assess in situ the survival of fish entering the $\mathrm{CW}$ system and put back to sea via the trash return system and effluent. The species tested were sole, dab, plaice, flounder, cod, whiting, pout (Trisopterus luscus (L)), bass, sprat, herring and brown shrimp (Crangon crangon). These trials were carried out both to validate the presumed efficacy of the system and to assuage concerns over the possible aesthetic nuisance from any beached dead fish. The then National Rivers Authority (NRA) had expressed concern that a trash return system would result in quantities of dead fish being washed onto the shore in the vicinity of Sizewell. To check for this, NRA staff conducted regular beach inspections both before and during the period of the trials, during which dead fish were de- 
liberately marked with dye and released via the outfall.

\subsection{Experimental Design}

A fish transport trailer, providing temperature and oxygen level control within a system of four 80 litre circular tanks, was used both to simulate water quality conditions and to hold fish for subsequent delayed examination. Water was pumped into the tanks from the forebay of the power station. The water temperature in the tank was adjusted to $10{ }^{\circ} \mathrm{C}$ above the ambient seawater temperature. This was achieved by the addition of seawater, electrically heated to a temperature of approximately $40^{\circ} \mathrm{C}$.

The trash return system was set to divert the catch towards the trash baskets for brief periods to allow experimental subjects to be collected. At all other times, the trash was directed via the system to the sea. Test animals were separated from the screen wash-water flow at the point of entry into the trash baskets, using a fine mesh Netlon" chute running into a tank of seawater. After fifteen to twenty minutes of collection time, the tank containing the catch was partly drained and the animals removed using a round-section fish scoop. Care was taken throughout the experiment to minimise the handling of the fish or shrimp.

Test animals were placed in a tank of chlorinated warm water for 10 minutes to simulate the maximum passage time in the heated discharge
(5 minutes caught in the turbulence in the surge shaft and 5 minutes travelling time in the culvert). Cold water, pumped directly from the forebay, was then added continuously to the tank for 24 hours. The cooling rate was designed to simulate the progressive dilution of the plume. This simulated the 'worst case' exposure conditions, where the fish drifted in the tide with the progressively diluting plume, rather than escaping from it vertically or laterally. The tanks were checked regularly during the retention period and any dead fish removed. Predatory fish were tested separately from their prey. The total test animal density in the tank varied between tests but, excepting small clupeids, never exceeded 50 per 80 litre tank.

At the end of the 24 hour experimental period the tank was drained and the number of surviving animals noted. They were then measured and their condition recorded. In 144 cases where fish died they were examined and, where appropriate, dissected to identify swimbladder or other internal damage (swimbladder damage may occur as a result of pressure changes to which the fish have been exposed (Turnpenny, 1992b).

The experimental protocols were established and maintained under Home Office licence.

Beaches in the vicinity of Sizewell Power Station site were inspected by the NRA both before and during the period when the fish return system was being assessed. The NRA followed a standard procedure including 
Table 14. - Survivorship of commercial species of fish and crustaceans through simulated Sizewell B power station trash return system.

Tableau 14. - Taux de survie d'espèces commerciales de poissons et de crustacés sur un système simulant le retour au milieu extérieur de la centrale de Sizewell B

\begin{tabular}{|c|c|c|c|c|c|c|c|c|c|}
\hline \multirow[b]{2}{*}{ Species } & \multirow{2}{*}{$\begin{array}{l}\text { Number } \\
\text { of Fish } \\
\text { Tested }\end{array}$} & \multirow{2}{*}{$\begin{array}{c}\text { Number } \\
\text { of } \\
\text { Replicates }\end{array}$} & \multirow{2}{*}{\multicolumn{2}{|c|}{$\begin{array}{l}\text { Number } \\
\text { Survived }\end{array}$}} & \multirow[t]{2}{*}{$\begin{array}{c}\% \\
\text { Survival }\end{array}$} & \multicolumn{2}{|c|}{$\begin{array}{c}\text { Standard length } \\
\text { of survivors } \\
(\mathrm{mm})\end{array}$} & \multicolumn{2}{|c|}{$\begin{array}{l}\text { Standard length } \\
\text { of mortalities } \\
(\mathrm{mm})\end{array}$} \\
\hline & & & & & & Mean & Std & Mean & Std \\
\hline Flounder & 15 & 11 & 15 & & 100.0 & 99.50 & 53.88 & NA & - \\
\hline Plaice & 4 & 4 & 4 & & 100.0 & 96.75 & 27.40 & NA & - \\
\hline Sole & 129 & 21 & 124 & & 96.1 & .160 .4 & 62.70 & 129.2 & 64.09 \\
\hline Cod & 47 & 16 & 44 & & 93.6 & 197.0 & $\begin{array}{r}44.90 \\
-\end{array}$ & 208.3 & -22.21 \\
\hline Bass & 37 & 11 & 33 & & 89.2 & 212.7 & 44.23 & 180.5 & 24.74 \\
\hline Dab & 10 & 8 & 8 & & 80.0 & 185.1 & 32.20 & 147.5 & 26.50 \\
\hline Whiting & 203 & 20 & 97 & & 47.8 & _ 180.6 & 55.55 & 146.2 & 50.30 \\
\hline Sprat & 94 & 3 & 0 & & 0.0 & NA & - & 98.09 & 27.02 \\
\hline Herring & 5 & 4 & 0 & & 0.0 & NA & - & 208.6 & 14.32 \\
\hline Shrimp & 635 & 8 & 599 & & 94.3 & NA & - & NA & - \\
\hline
\end{tabular}

Table 15. - Pathological findings on mortalities found within 24 hours of passage through the simulated return system.

Tableau 15. - Observations des pathologies liées à la mortalité sous $24 \mathrm{~h}$ lors du passage dans le système simulé de retour au milieu extérieur

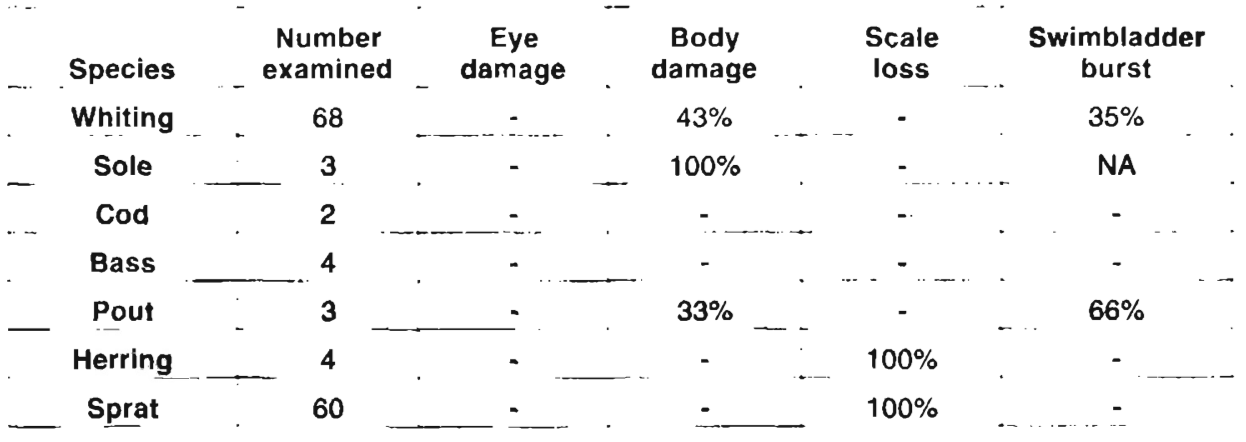

the establishment of control (no trash return) periods. To aid identification of fish originating from the Sizewell $B$ $\mathrm{CW}$ system, batches of dye-marked fish (total number $\sim 20,000$ ) were released into the return system during the survey period.

\subsection{Results}

Table 14 lists the survivorship results and Table 15 the findings of pathological investigations, which sought to identify the causes of mortality. 


\subsection{Conclusions}

- The trash return system at Sizewell B Power Station allowed viable return of several of the species tested. Flounder, plaice, sole, dab, and bass, all showed high survival rates $(80 \%)$, and whiting a lower rate $(48 \%)$. The system also returned brown shrimp, at a survival rate of $94 \%$. Survival of these species without the return system would be zero.

- Whiting mortality was probably due to burst swimbladders in $35 \%$ of cases.

- Sprat, herring, and pout suffered $100 \%$ mortality in the return system, probably due to osmotic collapse through scale loss.

- Differential tolerance to pressure variation appeared to account for the different mortality rates of gadoid species (cod, whiting).

- Differential tolerance to surface abrasion appeared to account for the high levels of flatfish survival compared with the mortality suffered by the more fragile pelagic clupeid species.

- The condition of the fish passing through the fish return system was much improved when compared to earlier studies on condition of impinged fish entering the trash baskets at other coastal power stations in England and Wales. This is probably due to the higher drum speed settings and the purpose designed gulleys.
- Over the 6 weeks of the return system trials the beach survey carried out by the National Rivers Authority found only one stranded fish. No dye-marked fish were found. There was no significant difference between the trial periods and controls as far as discoveries of other fish remains were concerned.

\section{OTHER FISH-RELATED STUDIES}

\subsection{Effects on Rare Fish and Invertebrate Species}

The effects of power station operation on rare fish species were also considered by NEL (Bamber 1992). The only rare species of concern at Sizewell were found to be the two shads occurring in British waters. Of the two, the rarer Allis shad (Alosa alosa) has not been recorded here since 1982, although occasional erratic migrants would be expected. With no spawning populations of either species on the East Coast of Great Britain recorded at this time, the occurrence of shad off Suffolk may be regarded as incidental and of negligible relevance to breeding stocks or population survival.

\subsection{Effects on Fish-eating Birds}

Concern was expressed by the Royal Society for the Protection of Birds (RSPB) over the potential impact of the Sizewell stations on fish- 
eating birds inhabiting their Reserve at Minsmere, Suffolk. Minsmere is an area of lakes, ponds, scrapes and low-lying marshland, sheltered from the sea by a shingle barrier, at what was the mouth of the Minsmere Haven. The birds in question include little terns (Sterna albifrons), sandwich terns (S. sandvicensis), common terns (S. hirundo) and other species such as the cormorant (Phalocrocorax carbo) and overwintering gulls. The concern related to possible effects on fish-eating birds, particularly breeding terns, caused by depletion of their food species, including sprat, herring and sand eel.

The matter was investigated using data from the 1981-2 survey on the $A$ station and from the 1994 surveys on the $A$ and $B$ stations (Bamber 1994). For little terns, sand eels form a major dietary component. The common sand eel (Ammodytes tobianus) was recorded at both stations, greater sand eel (Hyperoplus lanceolatus) only on the A Station, but both species were present only in very low numbers. A catch rate was calculated of 3.5 sand eels per day for the A station, and 10.5 per day for the $A$ and $B$ stations combined. Given that an adult little tern might catch 100 sand eels per day during the breeding season, the power stations losses represent the diet of only 0.1 little terns.

For the fish exploited by other fisheating bird species it was possible to cite the prior demonstration that captures by the power station were insignificant in comparison to a commercial trawler, noting that nobody had suggested that a single trawler is likely to adversely affect the food supply of such birds. It was also noted that the $B$ station returns fish to the sea and that gulls and other fish-eating birds tend to accumulate around the outfalls for feeding. Consequently, even though fish are temporarily removed by the $B$ station they become available to birds soon after at an increased rate than might otherwise be the case.

\subsection{Conclusions}

- The power stations have no effect on any rare fish or marine invertebrate.

- The power stations have no significant effect on the amount of food available to piscivorous birds.

\section{SYNTHESIS AND REAPPRAISAL}

\subsection{Introduction}

The preceding sections of this report have described the major studies that have been undertaken since 1981 in connection with the Sizewell Power Station sites. In this particular Section this information is used to provide a comprehensive assessment of the $A$ and $B$ stations' impact upon North Sea fisheries. Hence, the conclusions of earlier studies, undertaken jointly by Ministry of Agriculture, Fisheries and Food (MAFF) and the Central Electricity Generating 
Board (CEGB) in 1981/2 and on behalf of NEL are re-examined in the light of the more recent evidence.

In bringing up to date the 1992 analysis, the most important change is taking into account the effects of intake design and the fish return system on the estimates of the number of individuals killed. In the 1992 study it was assumed that the number of fish killed was directly proportional to the amount of water pumped from the sea; i.e. with approximately twice the amount of cooling water abstracted, it was assumed that the numbers of fish killed would be doubled. The studies carried out since 1992 and described in Sections 7 and 8 show that the B station would not produce a pro rata catch increase because of improvements in intake design and positioning relative to that of the $A$ station, and because of the use of the trash return facility. On the other hand, the additional and previously unquantified effects due to ichthyoplankton entrainment (Sections 5 and 6) can now be included.

\subsection{Operational Assumptions}

Although a substantial part of the more recent work undertaken at Sizewell related to a possible future $\mathrm{C}$ station development, there are no current plans for this. Therefore the only station combinations that need be considered are A plus B, the present operational situation. It is assumed for the present purpose that the $B$ station will be run with the fish return system always in operation, but that the A station will not, owing to the difficulties of retro-fitting such a system. Calculations are presented separately for the $A$ and $B$ stations, as the $B$ station is expected to be in operation many years after the closure of the A station.

\subsection{Reappraisal of Catches}

Table 16 summarises the figures used to adjust the A station data to allow for catch reductions due to $B$ station intake design and positioning, and due to operation of the $B$ station fish return system.

Figures given in Table 5 from the updated analysis of Sizewell A data represent the catch of fish in an average year, standardised for inter-annual fluctuations in CW consumption and in North Sea stock year-classstrength. The figures are given in Equivalent Adult terms. In Table 17, these are shown, along with EAV's for the losses due to entrainment, from which the total impingement + entrainment losses have been derived. The entrainment losses allow for the predicted survival rates for different species determined from the EMU studies (Section 6).

Figures for the $B$ station are also shown. The $B$ station impingement figures are calculated from the A station standardised catch (ATSC) figures, by first multiplying by 1.94 to account for the increase in $\mathrm{CW}$ flow rate $\left(50 \mathrm{~m}^{3} \mathrm{~s}^{1}\right.$, cf. $25.8 \mathrm{~m}^{3} \mathrm{~s}^{-1}$ average $\mathrm{CW}$ flow for the A station). The result 
Table 16. - The reduction in fish catch rates per unit volume of water pumped between the $A$ station intake system and that used for Sizewell B.

Tableau 16. - Réduction du taux de captures par unité de volume d'eau de refoidissement entre les tranches $A$ et $B$ de la centrale de Sizewell

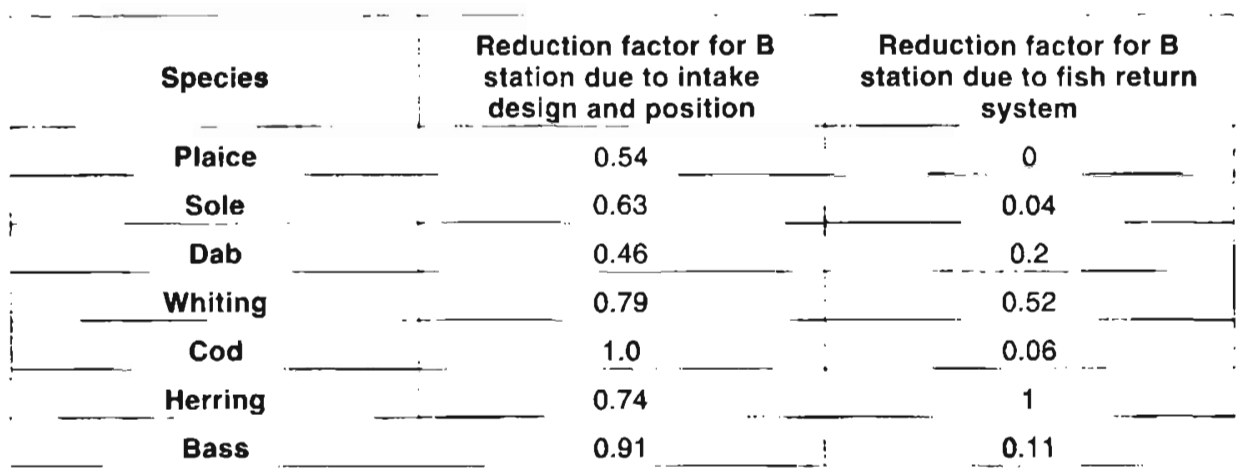

Table 17. - Annual standardised catch of commercial species due to impingement and entrainment, as equivalent adult tonnages, for the $A$ and $B$ stations, with the trash return system on the $B$ station operating (present operational regime).

Tableau 17. - Comparaison des captures d'espèces commerciales, exprimées en tonnages d'équivalent adulte, entre les tranches $A$ et $B$ de la centrale de Sizewell, cette dernière étant équipée d'un système de retour au milieu extérieur

\begin{tabular}{|c|c|c|c|c|c|c|}
\hline \multirow[t]{2}{*}{ Species } & \multicolumn{3}{|c|}{ A Station } & \multicolumn{3}{|c|}{ B Station } \\
\hline & Impinged & Entrained & Total & Impinged & Entrained & Total \\
\hline Plaice & $0.41 t$ & $2.34 t$ & $2.75 t$ & $0.00 \mathrm{t}$ & $4.54 \mathrm{t}$ & $4.54 t$ \\
\hline Sole & 4.01 & $19.5 \mathrm{t}$ & $23.5 \mathrm{t}$ & $0.20 \mathrm{t}$ & $37.8 t$ & $38.0 \mathrm{t}$ \\
\hline Dab & $2.30 t$ & $0.00 \mathrm{t}$ & $2.30 \mathrm{t}$ & $0.41 \mathrm{t}$ & $0.00 t$ & $0.41 \mathrm{t}$ \\
\hline Cod & $0.84 t$ & 0.001 & $0.84 t$ & $0.10 t$ & $0.00 t$ & $0.10 \mathrm{t}$ \\
\hline Whiting & $41.0 \mathrm{t}$ & $0.00 t$ & $41 \mathrm{t}$ & $32.7 t$ & $0.00 t$ & $32.7 t$ \\
\hline Herring & $51.0 t$ & $13.8 t$ & $63.8 \mathrm{t}$ & $73.2 \mathrm{t}$ & $26.7 t$ & $99.9 \mathrm{t}$ \\
\hline Bass & $0.35 t$ & $0.00 \mathrm{t}$ & $0.35 t$ & $0.07 t$ & $0.00 t$ & $0.07 t$ \\
\hline Total & $100 t$ & $35.6 \mathrm{t}$ & $135 t$ & $107 t$ & $69.0 \mathrm{t}$ & $176 t$ \\
\hline
\end{tabular}

is then multiplied by the factors given in Table 16 to allow for changes in intake design and positioning for the $\mathrm{B}$ station, and for operation of the fish return system. As no direct measurements of entrainment rates have been made for the $\mathrm{B}$ station, $\mathrm{A}$ station values pro rata with flow have been assumed. This is not unreasonable, as the ichthyoplankton distribution in the waters adjacent to the power stations is likely to be more uniform (or random) than that of older life stages, which occupy different habitats. Also, 
Table 18. - A comparison of commercial fish landings (1986-91) within ICES area IVc and equivalent adult captures of fish by the power stations at Sizewell under the current operating regime. Tableau 18. - Comparaison des prises de la péche commerciale (1986-91) dans le secteur ICES IVc avec les captures des centrales de Sizewell A et B.

\begin{tabular}{|c|c|c|c|c|}
\hline Species & $\begin{array}{l}\text { Commerclal } \\
\text { landings } \\
\text { in Tonnes }\end{array}$ & $\begin{array}{c}\text { A Station Loss } \\
\% \text { of Commercial } \\
\text { Landings }\end{array}$ & $\begin{array}{c}\text { B Station Loss } \\
\% \text { of Commercial } \\
\text { Landings }\end{array}$ & $\begin{array}{c}\text { Both Stations } \\
\% \text { of Commercial } \\
\text { Landings }\end{array}$ \\
\hline Plaice & 16,222 & $0.017 \%$ & $0.028 \%$ & $0.045 \%$ \\
\hline Sole & 4,048 & $0.58 \%$ & $0.94 \%$ & $1.52 \%$ \\
\hline Dab & 1,042 & $0.22 \%$ & $0.039 \%$ & $0.26 \%$ \\
\hline Cod & 25,163 & $0.003 \%$ & $<0.001 \%$ & $0.003 \%$ \\
\hline Whiting & 8,288 & $0.49 \%$ & $0.39 \%$ & $0.88 \%$ \\
\hline Herring & 2,823 & $2.3 \%$ & $3.5 \%$ & $5.8 \%$ \\
\hline Bass & 53 & $0.66 \%$ & $0.13 \%$ & $0.69 \%$ \\
\hline Total & 57,639 & $0.23 \%$ & $0.31 \%$ & $0.54 \%$ \\
\hline
\end{tabular}

there is less likelihood of the changes in intake design having any effect upon the capture rate of planktonic life stages.

Totals of $135 \mathrm{t}$ and $176 \mathrm{t}$, respectively for the $A$ and $B$ stations are indicated, demonstrating that the $\mathrm{B}$ station causes a loss of only $30 \%$ more fish than the A station, even though the $\mathrm{CW}$ demand is approximately double. In both cases the entrainment mortality accounts for around one-third of the total fish loss, by weight. Looking only at the impingement figures, Table 17 shows that, with improvements in intake design and the fish return system, the impingement rate at the $\mathrm{B}$ station is only $7 \%$ higher than that at Sizewell A. For reasons stated above, the entrained component for the $\mathrm{B}$ station has been raised by a factor of 1.94 (pro rata with flow) relative to the $\mathrm{B}$ station.

\subsection{Putting the Predicted}

Equivalent Adult Fish Losses into a Commercial Landings Context

Table 18 gives the average weight of fish landed per annum by all nations from ICES Area IVc (Southern North Sea) for years between 1986 and 1991. These can be considered typical figures for the region. The table compares the combined entrainment and impingement losses for each of the stations and for the $A$ and $B$ stations together. The overall losses relating to both stations amount to $0.54 \%$ of the average international landings of these species from Area IVc. The only species for which estimated losses exceed $1 \%$ of the commercial catch are the sole $(1.52 \%)$ and the herring $(5.8 \%)$.

Nevertheless, in considering these figures, it should be recognised that the Equivalent Adult procedure is a 
Table 19. - Average values of commercial fish in the Lowestoft market in July 1994, and estimated value of the equivalent adult loss on Sizewell $A$ and $B$ stations due to impingement and entrainment combined. (calculated from data in Table 17).

Tableau 19. - Valeur moyenne du cours du marché de Lowestoft en juillet 1994 et estimation de la valeur des captures, en équivalent adulte, dues aux centrales de Sizewell A et B (calculée d'après les données du tableau 17).

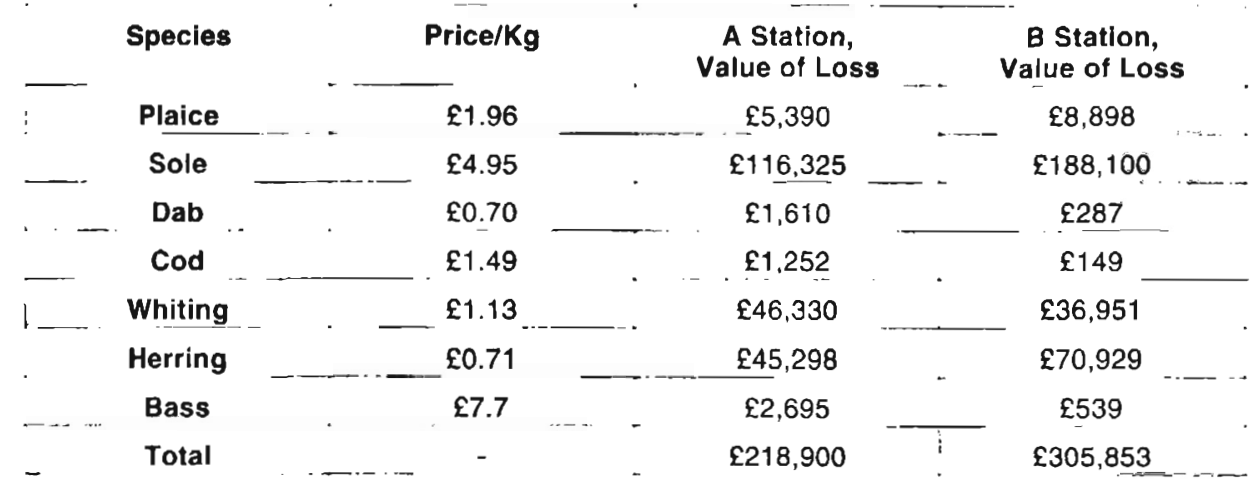

density-independent method, that is, it makes no allowance for possible compensatory mechanisms that operate in most animal populations through the lowering of resource constraints when population numbers are reduced (see e.g. Van Winkle, 1977). This would make the EAV estimates possibly excessive; unfortunately, there is no dependable method of allowing for these effects in our calculations. It will also be acknowledged by those familiar with fisheries statistics that these levels are within the 'noise' limits associated with measurement of fishery parameters.

\subsection{Monetary Values of the Predicted Equivalent Adult Fish Losses}

To give a monetary value to the loss, market prices collected during
July 1994 and tabulated in Table 19 were used. This indicates a potential combined loss of fish to the value of £0.52 million per annum. It will be noted that the value shown for the $A$ station losses is more than twice that quoted in Section 5.3, which was based on 1991 prices.

Again, it should be emphasised that these may be overestimates, owing to the absence of any allowance for density dependent effects referred to in the previous Section.

\subsection{Acoustic Deterrent Technology}

Separately from the Sizewell fisheries assessment work, NEL undertook field trials of an acoustic fish deterrent system that had evolved through a development programme instigated by the CEGB. Such acous- 
tic fish deterrent (AFD) systems may be placed around $C W$ intakes with the intent of repelling fish from the intake area and so help reduce fish ingress. This has obvious possible benefits over the fish return approach, in that the fish are kept away from any sort of handling stress and are therefore more likely to survive. In practice, fish return systems and AFD systems offer complementary approaches. Acoustic deterrents have been found to be most effective against species such as sprat and herring, which are 'hearing specialists', moderately effective against other swimbladder species such as the gadoid fish, and much less effective against benthic and non-swimbladder species such as the flatfish. This pattern is the reverse of the effect seen with fish return systems, which favour robust, benthic species and are ineffective for the delicate pelagic fish.

While AFD systems have not been used at either of the Sizewell Power Stations, trials have been undertaken by NEL at Hinkley Point (Turnpenny et al., 1994) and Hartlepool power stations (Turnpenny et al, 1995). In both instances the layout of the intake structures allowed ready access, but whilst at Hartlepool the intake was onshore at the head of a partially enclosed channel, the Hinkley intake structure was offshore. This had none of the potential advantages in terms of optimising the sound field conferred by partial enclosure. The Hinkley Point trials, which were joint funded on behalf of the then Department of Energy as part of the generic tidal power programme, suffered technical problems and, owing to characteristics of the sound field generated, actually increased the overall catch of fish by around $50 \%$. Although this was not the desired effect it did confirm that sound could be used to modify the behaviour of fish and therefore the further trial, at Hartlepool power station, was instigated.

The Hartlepool trials used improved sound generating technology and an acoustical modeling procedure (PrISM) which allowed for better placement of the acoustic sources to achieve the desired sound field. A significant degree of deterrence was achieved. The overall efficiencies for different categories of fish, and their statistical significance (t-test: difference from zero), as determined from a 42 day trial period of alternating sound-on and sound-off days, were as follows:

* all species combined

* sprat

* herring

* whiting

- $56 \%(p<05)$

* other swimbladder species

- $55 \%(p<05)$;

* non-swimbladder species

- $16 \%(p<0.05)$.

A cost benefit appraisal of such systems was commissioned by NEL, and this study involved underwater acoustic monitoring and preliminary acoustic field modeling at each of its operational sites. In reviewing this appraisal, although the Hartlepool trial 
showed that such a system was a practicable option for that site, the difficulty of positioning and maintaining a sufficiently wide spread of seabedmounted acoustic sources around the offshore Sizewell B intake is presently considered to be impracticable.

\subsection{Conclusions}

- Comparison of the predicted losses of commercial fish species due to impingement and entrainment at Sizewell A and B Power Stations with commercial landings from adjacent waters (ICES area IVc) shows that the power stations losses amount to about half of one percent $(0.54 \%)$ of the recorded UK and international landings when expressed in Equivalent Adult terms. Of the individual species, Equivalent Adult losses of only sole $(1.5 \%)$ and herring $(5.8 \%)$ exceeded one per cent of the commercial landings figures.

- The commercial value of the losses due to both stations is estimated at E0.52 million per annum (1994 values), with the bulk of this value being ascribed to losses of sole ( $\{304,425: 93 \%$ as entrained eggs, remainder impinged), whiting ( $\{83,821 ; 100 \%$ as impinged juveniles or adults) and herring ( $\{116,227: 24 \%$ as entrained larvae/post-larvae, remainder impinged).

- The commercial value of the loss due to the B station $(£ 305,853)$ is estimated to be only $40 \%$ higher than that due to the A station, despite the fact that the $C W$ demand is twice as large. This reflects improvements in intake design and location, and the successful operation of the trash return system on the B station.

- All of the above estimates are based on the Equivalent Adult evaluation method. This does not take account of possible densitydependent population regulation mechanisms, which may serve in practice to reduce the predicted levels of effect. The figures should therefore be regarded as overestimates.

- The trash return system at Sizewell $B$ allows viable return to sea of several of the more significant species involved. Flounder, plaice, sole, dab and bass all have been shown to have high survival rates through the system $(80 \%)$, and whiting a lower rate $(48 \%)$. The system also returns brown shrimp, at a survival rate of $90 \%$. Survival of these species without the return system would be zero.

- Trials of an acoustic deterrent system associated with the on-shore intake at Hartlepool Power Station on the Tees estuary have shown that significant reductions in impingement rates $(16-80 \%$, depending on species) can be achieved. An acoustic system could have benefits at Sizewell but the practicability of establishing and maintaining a wide spread of permanent seabed acoustic sources around such an offshore intake is considered to be 
low. Given the proven success of the existing mitigative measures at Sizewell B (relating to intake design and position, and the return system) an acoustic system is not recommended as a priority at this particular site.

\section{ACKNOWLEDGEMENTS}

We wish to thank British Energy and the Sizewell A\&B Nuclear Power Stations for their support for enabling this study and for permission to publish.

\section{REFERENCES}

Bamber, R N, 1994. The potential effects of Sizewell Nuclear Power Stations on the food of piscivorous birds at Minsmere. Report to Nuclear Electric by Fawley arl Ltd. CAR 117/94.

Bamber, R N, Seaby, R M H, Turnpenny, A W H and Fleming, J M, 1993. Sizewell ichthyoplankton survey, 1992-3. Report to Nuclear Electric by Fawley arl FCR074/93.

Bamber R N \& Seaby R M H (1993). The effects of entrainment passage on planktonic stages of sole and turbot. Report to Nuclear Electric by Fawley arl FCR 054/93.

Bamber R N \& Seaby R M H (1994a). The effects of entrainment passage on the planktonic copepod Acartia tonsa Dana. Report to Nuclear Electric by Fawley arl FRR 108/94.

Bamber, R N and Seaby, R M H (1994b). The effects of entrainment passage on planktonic stages of sole, Solea solea L. Report to Nuclear Electric by Fawley arl FRR097/94.

Bamber R N \& Seaby R M H (1994c). The effects of entrainment passage on the planktonic larvae of the lobster. Report to Nuclear Electric by Fawley arl FRR $103 / 94$.

Bamber R N \& Seaby R M H (1994d). The effects of entrainment passage on the planktonic larvae of the common shrimp. Report to Nuclear Electric by Fawley arl FCR 095/94.

Bamber R N \& Seaby R M H (1995a). The effects of entrainment passage on the planktonic larvae of the mussel, Mytilus edulis L. Report to Nuclear Electric by Fawley arl FRR 162/95.

Bamber R N, Seaby, R M H, Fleming J M and Taylor, C J L (1994). The effects of entrainment passage on embryonic development of the Pacific oyster Crassostrea gigas. Nuclear Energy 33 (6) 353-357.

Bamber, R N and Seaby, R M H (1995). The effects of entrainment passage on planktonic stages of the bass, Dicentrarchus labrax (L.). Report to Nuclear Electric by FAWLEY arl FRR160/95.

Coughlan, $\mathrm{J}$ and Davis, $\mathrm{M} \mathrm{H}, 1985$. Concentrations of chlorine around marine cooling water outfalls: validation of a model. In: "Water Chlorination: Environmental Impact and Health Effects, Volume 5", (Ed. Jolley, R L, Bull, R J, Davis, W P, Katz, S, Roberts, M H Jr, and Jacobs, $\vee$ A). Chelsea, Michigan, Lewis Publishers Inc., 1459-1468.

Fleming, J M, Seaby, R M H and Turnpenny, A W H, 1994. A comparison of fish impingement rates at Sizewell $A$ \& $B$ Power Stations. Report to Nuclear Electric by Fawley arl FCR104/94.

Fowler, $J$ and Cohen, L, 1990. Practical Statistics for Field Biology. Open University Press, Milton Keynes, UK.

Henderson, P A, 1989. On the structure of the inshore fish community in England and Wales. J. Mar. Biol. Ass. UK, 69, 145-163.

Kelley, D F, 1988. Age determination in bass and assessment of growth and year-class strength. J. mar biol. Ass. UK, 68, pp 179-214. 
Murarka, I P and Bodeau, D J, 1977. Sampling designs and methods for estimating impingement losses at cooling water intakes. Report of the Argonne Nat. Lab., Argonne, Illinois, ANLES/ 60.

Rahman, N A, 1968. Introduction to Statistical Theory. London, Charles Griffin \& Co., 293-299.

Ricker, W E, 1975. Computation and Interpretation of Biological Statistics of Fish Populations. Bulletin 191, Fish. Res. Bd Can., pp. 8-10.

Riley, J D, Symonds, D J and Woolner, L, 1981. On the factors influencing the distribution of 0-group demersal fish in coastal waters. Rapp. P.-v. Reun. Cons. Int. Explor. Mer, 178, 223-228.

Riley, J D and Parnell, W G, 1984. The distribution of young cod. Floddevigen rapportser, 1, 563-580.

Russell, F, 1976. The Eggs and Planktonic Stages of British Marine Fishes. London, Academic Press, 524 pp.

Seaby, $R M H, 1994$. Survivorship trial of the fish-return system at Sizewell B Power Station. Report to Nuclear Electric, by Fawley arl FCR102/94.

Symonds, D J, Davies, I L and Brander, K $M, 1985$. Effect of a small-meshed fishery on the stocks of pre-recruit plaice and sole. International Council for the Exploration of the Sea, ICES CM 1985/G:28, 14pp.

Turnpenny, A W H, Utting, N J, Millner, R $S$ and Riley, J D, 1983. The effect of fish impingement at Sizewell A Power Station, Suffolk, on North Sea fish stocks Central Electricity Generating Board, Sizewell Public Inquiry Support Document No. CGEB/S/380, 27pp. + Appendices.

Turnpenny, A W H, 1988a. The behavioural basis of fish exclusion from coastal power station cooling water intakes. Central Electricity Generating Board, Research Report No. TPRD/L/3270/ R88, 28pp. + Figs. + Tables.

Turnpenny, A W H, 1988b. Fish impingement at estuarine power stations and its significance to commercial fishing. J. Fish Biol., 33 (Suppl. A), pp. 103-110.

Turnpenny, A W H,1989a. The equivalent adult approach for assessing the value of juvenile fish kills, with reference to commercial species in British waters. Central Electricity Generating Board, Research Report No. RD/L/3454/R89, 9pp. + Figs. + Tables.

Turnpenny, A W H, 1989b. Impoundment and abstraction - exclusion of fish from intakes. In: "Water Scheme: the Safeguarding of Fisheries" (Ed. Gregory, J). Pitlochry, Atlantic Salmon Trust.

Turnpenny, A W H,1992. Sizewell: Fish by-catch in the East Coast shrimp fishery. Report to Nuclear Electric by Fawley arl FCR 012/92.

Turnpenny, A W H, 1992. Fish return at cooling water intakes. Report to Nuclear Electric by Fawley arl FCR 023/92.

Turnpenny, A W H and Coughlan, J, 1992. Power generation on the British Coast: thirty years of marine biological research. Hydroecol. Appl., 4(1), 1-11.

Turnpenny, A W H and Henderson, P A, 1993. Sizewell: Reappraisal of fish impingement at the A station and implications of multiple plant operation. Report to Nuclear Electric by Fawley arl FCR 014/92.

Turnpenny, A W H, Wood, R and Thatcher, KP, 1994. Fish deterrent trials at Hinkley Point Power Station, Somerset, 1993-4. Report to Nuclear Electric by Fawley arl FCR 132/94.

Turnpenny, A W H, Fleming, J M, Thatcher, KP and Wood, R, 1995. Trials of an acoustic fish deterrent system at Hartlepool Power. Report to Nuclear Electric by Fawley arl FCR 163/95.

Van Winkle, W, 1977. Assessing the effects of power-plant-induced mortality on fish populations. Proceedings of a Conference held at Riverside Motor Lodge, Gatlinburg, Tennessee, USA, May 3-6 1977 (Ed. Van Winkle, W). New York, Pergamon, 380 pp. 